\title{
The composition of nucleation and Aitken modes particles during coastal nucleation events: evidence for marine secondary organic contribution
}

\author{
P. Vaattovaara ${ }^{1}$, P. E. Huttunen ${ }^{2}$, Y. J. Yoon ${ }^{4, *}$, J. Joutsensaari ${ }^{2}$, K. E. J. Lehtinen ${ }^{3}$, C. D. O'Dowd ${ }^{4}$, and \\ A. Laaksonen ${ }^{1}$ \\ ${ }^{1}$ University of Kuopio, Dept. of Physics, P.O. Box 1627, 70211 Kuopio, Finland \\ ${ }^{2}$ University of Kuopio, Dept. of Environmental Sciences, P.O. Box 1627, 70211 Kuopio, Finland \\ ${ }^{3}$ University of Kuopio and Finnish Meteorological Institute, Dept. of Physics, P.O. Box 1627, 70211 Kuopio, Finland \\ ${ }^{4}$ Dept. of Experimental Physics and Environmental Change Institute, National University of Ireland, Galway, Ireland \\ *now at: Korea Polar Research Institute, Songdo Techno Park, 7-50, Singdo-dong, Incheon 406-840, Republic of Korea
}

Received: 18 January 2006 - Published in Atmos. Chem. Phys. Discuss.: 21 April 2006

Revised: 4 October 2006 - Accepted: 11 October 2006 - Published: 12 October 2006

\begin{abstract}
Newly-formed nanometer-sized particles have been observed at coastal and marine environments world wide. Organic species have so far not been detected in those newly-formed nucleation mode particles. In this study, we applied the ultrafine organic tandem differential mobility analyzer method to study the possible existence of an organic fraction in recently formed coastal nucleation mode particles $(d<20 \mathrm{~nm})$ at the Mace Head research station. Furthermore, effects of those nucleation events on potential cloud condensation nuclei were studied. The coastal events were typical for the Mace Head region and they occurred at low tide conditions during efficient solar radiation and enhanced biological activity in spring 2002. Additionally, a pulse height analyzer ultrafine condensation particle counter technique was used to study the composition of newly-formed particles formed in low tide conditions during a lower biological activity in October 2002. The overall results of the ultrafine organic tandem differential mobility analyzer and the pulse height analyzer ultrafine condensation particle counter measurements indicate that those coastally/marinely formed nucleation mode particles include a remarkable fraction of secondary organic products, beside iodine oxides, which are likely to be responsible for the nucleation. During clean marine air mass conditions, the origin of those secondary organic oxidation compounds can be related to marine coast and open ocean biota and thus a major fraction of the organics may originate from biosynthetic production of alkenes such as isoprene and their oxidation driven by iodine radi-
\end{abstract}

Correspondence to: P. Vaattovaara

(petri.vaattovaara@uku.fi) cals, hydroxyl radicals, acid catalysis, and ozone during efficient solar radiation. During modified marine conditions, also anthropogenic secondary organic compounds may contribute to the nucleation mode organic mass, in addition to biogenic secondary organic compounds. Thus, the ultrafine organic tandem differential mobility analyzer results suggest that the secondary organic compounds may, in addition to being significant contributors to the nucleation mode processes, accelerate the growth of freshly nucleated particles and increase their survival probability to cloud condensation nuclei and even larger radiatively active particle sizes. The results give new insights to the marine/coastal particle formation, growth, and properties. The marine biota driven secondary organic contributions to marine/coastal particle formation and composition can be anticipated in other species specific biologically active oceans and fresh-waters areas around the world and thus, they may be significant also to the global radiative bugdet, atmosphere-biosphere feedbacks, and climate change.

\section{Introduction}

Bursts of nanometer-sized particles formed from nucleated atmospheric gases and grown to detectable sizes (i.e. nucleation events) have been observed at coastal and marine environments around the world (see Kulmala et al., 2004a). Such nanoparticles can grow into larger sizes (O'Dowd, 2001), being able to scatter incoming radiation and contribute a direct and an indirect (via clouds) cooling effect to the Earth's radiation budget (Slingo, 1990). However, because of difficulties

Published by Copernicus GmbH on behalf of the European Geosciences Union. 

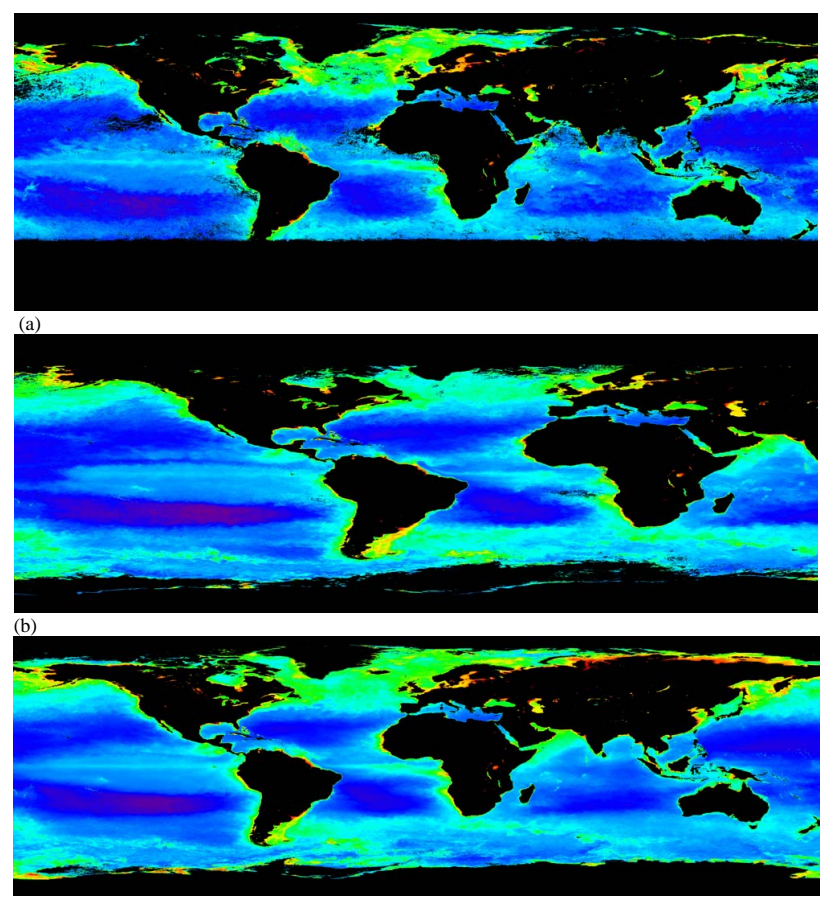

(c)

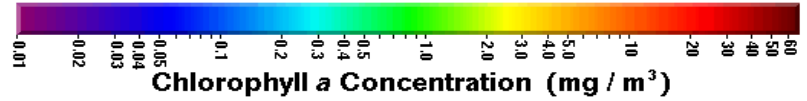

Fig. 1. SeaWiFS (Sea-viewing Wide Field-of-view Sensor) satellite pictures (NASA/Goddard Space Flight Center and ORBIMAGE) about surface waters biological activity. Note that chlorophyll a mass concentration $\left(\mathrm{mg} / \mathrm{m}^{3}\right)$ typically increases toward the coastlines; (a) The EBA (compared to autumn and average) at the Northern hemisphere in the spring 2002; (b) The LBA at the Northern hemisphere in the autumn 2002; (c) Global average biological activity during the year 2002 .

related to the determination of the chemical composition of ultrafine aerosol particles, the organic contribution to the nucleation mode $(\mathrm{d}<20 \mathrm{~nm})$ and the lower end of Aitken mode particles $(d<50 \mathrm{~nm})$ in different coastal and marine environments is still widely undetermined. From the viewpoint of coastal and marine climate processes (e.g. Novakov and Penner, 1993; Andreae and Crutzen, 1997; Alfonso and Raga, 2004), it would be important to know whether those particles contain also organic compounds.

We carried out this study of coastal nucleation and Aitken modes particles composition on the shore of the Atlantic Ocean in West Ireland (Mace Head), where new particle formation events are known to occur during daylight hours coinciding with the low tide and the source of aerosol precursors in the exposed tidal zone (O'Dowd, 2000). Related to the coastal nucleation events, it has been demonstrated in chamber experiments (e.g. O'Dowd et al., 2002a; Jimenez et al., 2003; Burkholder et al., 2004) and by analyzing ultrafine Transition Electron Microscopy (TEM) samples from the coastal biota (Mäkelä et al., 2002) that new particles can form from condensable iodine-containing vapors, which are the products of photolysis followed by chemical reactions of biogenic iodocarbons $\left(\mathrm{CH}_{2} \mathrm{I}_{2}\right)$ emitted from the marine algae at the biogenically rich coastal environment. The recent chamber study of McFiggans et al. (2004) showed that emission of $I_{2}$ from the macroalgae and subsequent ozonolysis would also be a very potential source of iodine oxides and new particle formation in the Mace Head area. That observation has also been promoted by experiments of Sellegri et al. (2005) and Palmer et al. (2005). Furthermore, the very recent study of Saunders and Plane (2005) indicated that ozonolysis of $\mathrm{I}_{2}$ produce $\mathrm{I}_{2} \mathrm{O}_{5}$ particles. As a consequence of those studies, probable iodine oxides for new particle formation could be $\mathrm{I}_{2} \mathrm{O}_{4}$ and $\mathrm{I}_{2} \mathrm{O}_{5}$. In addition to iodine compounds, TEM samples (Mäkelä et al., 2002) and UFHTDMA (ultrafine hygroscopicity tandem differential mobility analyzer) measurements (Väkevä et al., 2002) have shown that sulfate $\left(\mathrm{SO}_{4}^{2-}\right)$, the formation of which can originate via DMS (dimethyl sulfite) from algae or sulfur from antropogenic origin, is only a minor constituent in those newlyformed nanometer-sized particles. In addition, even though a small amount of biogenically formed sulfuric acid is always present during new particle formation events at Mace Head, no correlation has been found between peak sulfuric acid concentrations and low tide occurrence or nucleation events (O'Dowd, 2000). Additionally, it has also been pointed out that sulfuric acid concentrations can not be responsible for nucleation mode particle growth to the detectable sizes (i.e. $>3 \mathrm{~nm}$ in diameter) at the Mace Head site (O'Dowd et al., 2002b).

Interestingly, the possible presence of organic species in the coastal newly-formed particles has not been investigated with methods which would be able to detect organics. In this study, we applied the UFO-TDMA (ultrafine organic tandem differential mobility analyzer; Vaattovaara et al., 2005) method to highlight the existence of an organic fraction in recently formed coastal nucleation mode particles $(d<20 \mathrm{~nm})$ during a three weeks intensive spring campaign (21 May 2002-10 June 2002). Furthermore, effects of those nucleation events to potential CCN (cloud condensation nuclei) were studied. The coastal events were typical for the Mace Head region and they occurred at low tide conditions during efficient solar radiation and enhanced biological activity (EBA, i.e. an enhanced mass concentration of chlorophyll a of the Atlantic Ocean) in spring 2002 (Fig. 1a). The main focus was put on two of the strongest events with clean marine air (4 June) and with modified marine air (6 June), and on a clean event with air mass direction change from the coastal region to open ocean (27 May).

Additionally, a PHA-UCPC (pulse height analyzer ultrafine condensation particle counter) technique (O'Dowd et al., 2004a) was used to study the composition of newly-formed particles at a clean marine air low tide condition autumn day (8 October 2002) during a lower biological activity (LBA, i.e. 


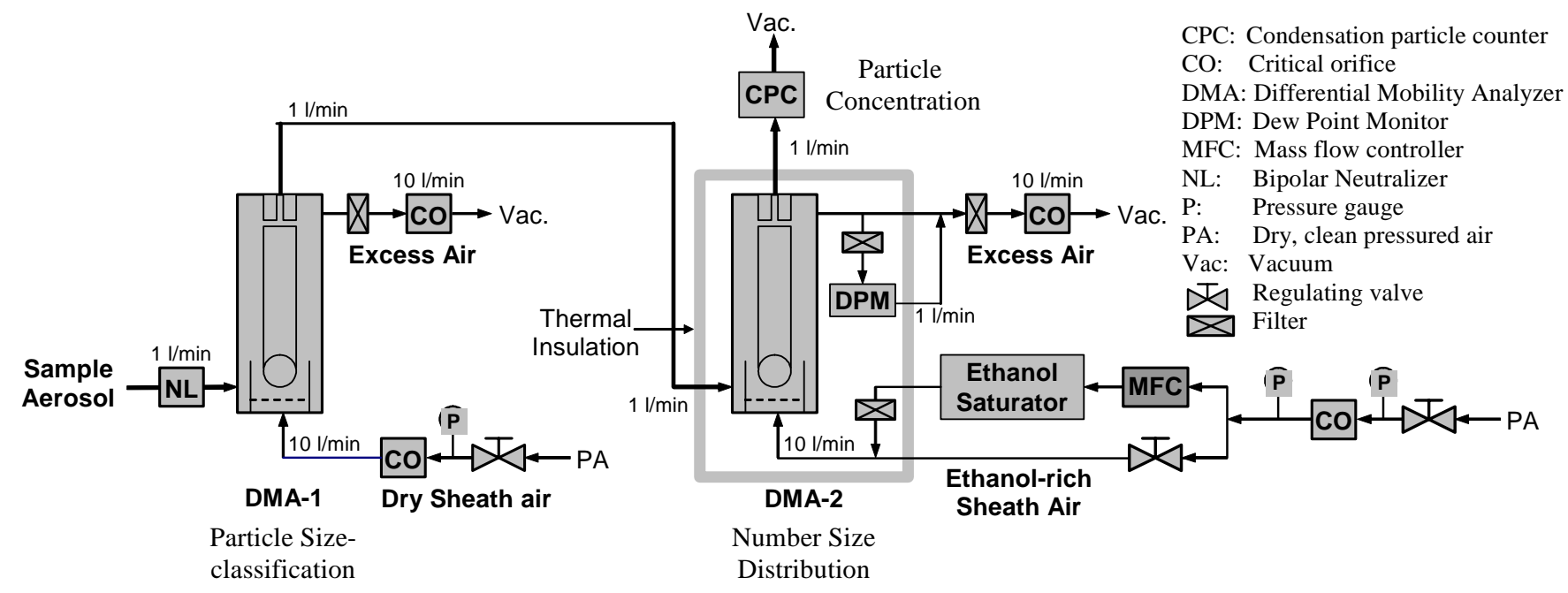

Fig. 2. A schematic picture of the UFO-TDMA system.

a lower mass concentration of chlorophyll a of the Atlantic Ocean; Fig. 1b).

\section{Methods}

\subsection{The UFO-TDMA}

The ultrafine organic tandem differential mobility analyzer (UFO-TDMA) was applied to shed light on the possible presence of an organic fraction in the nucleation mode particles. Details of the system have been presented by Joutsensaari et al. (2001) and Vaattovaara et al. (2005). A brief summary of the UFO-TDMA setup and method used in this study is given in the following sections.

Figure 2 shows a schematic diagram of the UFO-TDMA setup. The first (Hauke type, length $11 \mathrm{~cm}$; Winklmayr et al., 1991) DMA (differential mobility analyzer) classifies a desired size (for example, $10 \mathrm{~nm}$ ) from a polydisperse aerosol flow, after which the selected particles are introduced to air with a known solvent (i.e. ethanol) saturation ratio $S$. The second DMA (Hauke type, length $11 \mathrm{~cm}$; Winklmayr et al., 1991) then measures the change in particle size due to the interaction with the subsaturated ethanol vapor. The growth factors (GF), i.e. the final diameter after vapor uptake divided by the initial "dry" diameter of the particles are characteristic for each particle composition. In order to apply the dew point meter for ethanol vapor (if water is excluded, ethanol can be measured; Schultz G., private communication, 29.2.2000), dried and purified sheath air as well as Nafion dried aerosol flow (water saturation ratio $\sim 0.01$ ) was used. The temperature difference was maximized to $25 \mathrm{~K}$ between the saturator and the condenser in the CPC (condensation particle counter, 3010, TSI; Quant et al., 1992) to detect particles down to $6 \mathrm{~nm}$ (Mertes et al., 1995). During the daytime ex- periments of this study, the ethanol (purity $99.8 \%$ ) saturation ratios were about 0.86 and the dry particle diameters were 6 , $8,10,30$, and $50 \mathrm{~nm}$, respectively.

The basic principle of the organic fraction detection in coastal environment is based on our laboratory UFO-TDMA measurements (Vaattovaara et al., 2005) with the most relevant inorganic compounds of biogenic origin believed to be present in the coastal aerosols and with two relevant oxidized organic compounds. The investigated compounds included sodium chloride $(\mathrm{NaCl}$, a major constituent of marine sea salt particles with decreasing trend from coarse mode toward the upper end of Aitken mode particles; O'Dowd et al., 2004b), iodine tetroxide $\left(\mathrm{I}_{2} \mathrm{O}_{4}\right)$, iodine pentoxide $\left(\mathrm{I}_{2} \mathrm{O}_{5}\right)$, ammonium sulfate $\left(\left(\mathrm{NH}_{4}\right)_{2} \mathrm{SO}_{4}\right)$, ammonium bisulfate $\left(\left(\mathrm{NH}_{4}\right) \mathrm{HSO}_{4}\right)$, and several mixtures of ammonium bisulfate and sulfuric acid $\left(\mathrm{H}_{2} \mathrm{SO}_{4}\right)$. Measurements were also done for two water soluble organic compounds, citric acid $\left(\mathrm{C}_{6} \mathrm{H}_{8} \mathrm{O}_{7} \mathrm{H}_{2} \mathrm{O}\right)$ and tartaric acid $\left(\mathrm{C}_{4} \mathrm{H}_{6} \mathrm{O}_{6}\right)$. Citric acid is an important compound of the Krebs cycle of the metabolism of aerobic cells and organisms (Zubay, 1998). Citric acid has also been shown to be an important species in marine waters at the Atlantic coast (Creac'h, 1955) and sea salt particles (Ming and Russell, 2001). For tartaric acid, biogenic origin has been suggested too (Röhrl and Lammel, 2002). Tartaric acid has been known to be present at least in some fruits (Streitwieser et al., 1992) and synthesised from vitamin $\mathrm{C}$ in higher plants (DeBolt et al., 2006). Interestingly, tartaric acid molecular formula has common features with oxidations products of a marine biota produced organic compound (i.e. isoprene, $\mathrm{C}_{5} \mathrm{H}_{8}$ ).

Our laboratory measurements indicated (Vaattovaara el al., 2005 ) that the inorganic compounds do not grow in subsaturated ethanol vapor, when particle size is $10 \mathrm{~nm}$ in diameter or below, and when the saturation ratio is about $86 \%$ or below. Furthermore, internally mixed $10 \mathrm{~nm}$ particles 


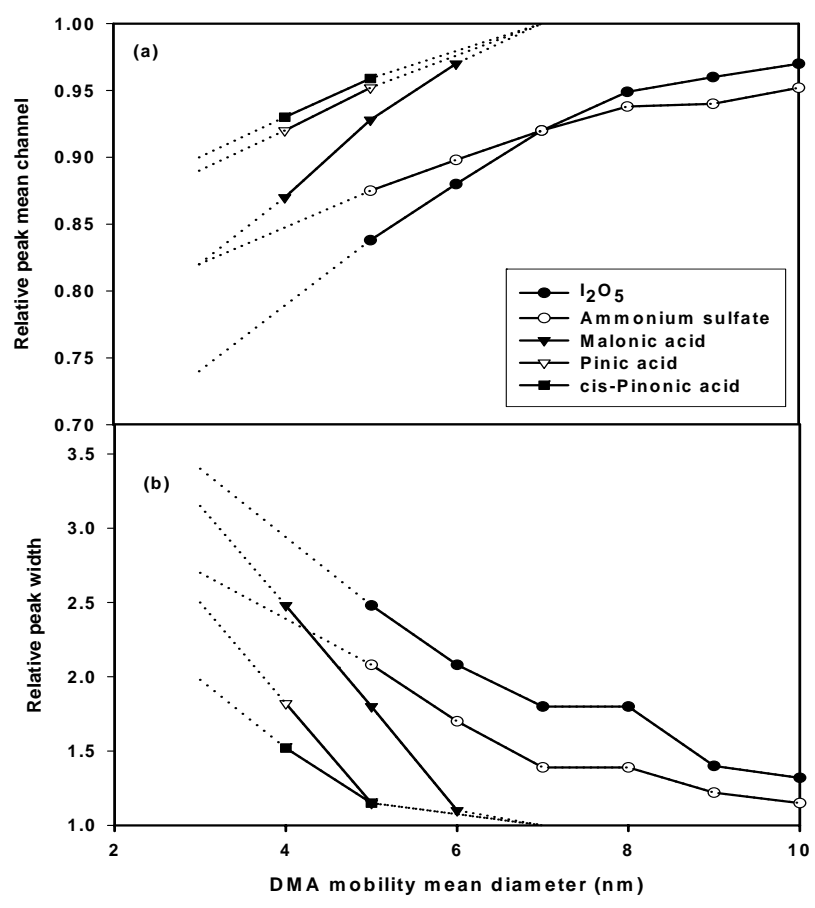

Fig. 3. (a) Relative peak mean channel and (b) Relative peak width as a function of DMA mobility mean diameter (O'Dowd et al., 2004a).

composed of ammonium bisulfate and sulfuric acid with sulfuric acid mass fraction $\leq 18 \%$ showed no growth at $86 \%$ saturation ratio. That kind of sulfuric acid mass fraction should be much more than what can be present during new particle formation events at Mace Head (O'Dowd, 2000). Furthermore, it is expected that sulfuric acid is neutralized to more ammonium bisulfate and ammonium sulfate like forms in the aqueous particle phase (Seinfeld and Pandis, 1998).

In contrast to inorganics, $10 \mathrm{~nm}$ particles composed of the oxidized organic compound studied did grow at ethanol saturation ratio of 0.86. The properties of the different compounds studied are summarised in Table 1. Qualitatively, the growth behavior of those compounds in ethanol $(\mathrm{EtOH})$ is as expected based on the solubility information. For more detailed growth behavior, Table 2 shows the ethanol growth factors of three individual compounds and a sulfuric acid mixture with ammonium bisulfate $(6 \mathrm{~nm}$ and $8 \mathrm{~nm}$ have not been measured for the mixture, because $10 \mathrm{~nm}$ did not grow) as a function of particle diameter at saturation ratios about 85 $86 \%$.

\subsection{The PHA-UCPC}

The characterisation of the PHA-UCPC (pulse height analyzer ultrafine condensation particle counter) was conducted in the Department of Physical Sciences, University of Helsinki, and has been reported in detail by O'Dowd et al. (2004a). In the PHA-UCPC, particles grow in supersaturated butanol vapour and are detected optically. The size of the grown droplet depends on the initial particle diameter when it is smaller than about $10 \mathrm{~nm}$, and therefore the initial particle size can be obtained from the pulse heights of the optical detector, provided that the instrument has been properly calibrated. However, also the composition of the particles affect the measurement: particles composed of butanol soluble substances (e.g. organic acids) start growing at an earlier point inside the instrument than do butanol insoluble particles (e.g. iodine oxide particles) and appear therefore larger than they really are if the calibration has been done using insoluble particles. As shown by O'Dowd et al. (2004a), the instrument can therefore be used to infer information about particle compositions. Here, we summarize the most important results from the viewpoint of the present study.

Responses by the PHA-UCPC for various particle compositions were tested. The tested aerosol species were (1) iodine pentoxide (iodine oxide used as a surrogate for $\mathrm{I}_{2} \mathrm{O}_{4}$ which is thought to be present in coastal nucleation mode particles (Hoffmann et al., 2001; Mäkelä et al., 2002), (2) ammonium sulfate, (3) malonic acid $\left(\mathrm{C}_{3} \mathrm{O}_{4} \mathrm{H}_{4}\right.$, a known anthropogenic organic aerosol species), (4) pinic acid $\left(\mathrm{C}_{9} \mathrm{H}_{14} \mathrm{O}_{4}\right)$ and (5) cis-pinonic acid $\left(\mathrm{C}_{10} \mathrm{H}_{16} \mathrm{O}_{3}\right)$. The nonatmospheric aerosol type chosen was silver (Ag).

Calibration particles, with the exception of silver particles which were produced with a tube furnace, were generated from an atomizer using water as a solvent. Calibrations were conducted for a range of sizes from 3-10 nm. For each calibration, large $(20 \mathrm{~nm})$ silver particles were also produced with a tube furnace to determine the primary pulse "anchor" spectrum. For the sub $10 \mathrm{~nm}$ silver calibrations, $20 \mathrm{~nm}$ ammonium sulfate particles, produced with the atomizer, were used to determine the primary pulse spectrum.

During all calibrations, the $20 \mathrm{~nm}$ particles produced narrow spectra centered on the channel number 800 of the MCA (multi-channel analyser) because these particles have already grown in the condensation chamber in a CPC to produce equivalent pulse strengths, as observed in the field experiments. The $5 \mathrm{~nm}$ diameter particles for the 4 species tested exhibit noticeably different peak intensities and peak widths. The $5 \mathrm{~nm}$ diameter ammonium sulfate particles, as previously demonstrated (Weber et al., 1997) exhibit a peak at the MCA channel number 700, while $\mathrm{I}_{2} \mathrm{O}_{5}$ particles of the same size exhibit a peak at MCA channel number 670. Pinic acid exhibits peak intensity at MCA channel 760 . It should be noted that the locations of the peak channel in the normalized counts are dependent on the size of particles, moving toward higher channel for larger particles used in the calibration, while the width of the spectrum decreases with size.

A series of PHA-UCPC laboratory calibration for a range of particle sizes between $3 \mathrm{~nm}$ and $10 \mathrm{~nm}$ was conducted for the aforementioned species. Pulse height spectra for all particles were fitted with normal distributions and the peak channel positions and widths were calculated. The results of the 
Table 1. Some information about $10-50 \mathrm{~nm}$ particles composed of individual compounds measured by the UFO-TDMA (Vaattovaara et al., 2005). The abbreviations i, sl, s and vs stand for insoluble, slightly soluble, soluble, and very soluble, respectively. The supercripts ${ }^{1},{ }^{2}$ and 3 mean Daehlie and Kjekshus (1964), CRC Handbook of Chemistry and Physics (1996), and Vaattovaara et al. (2005), respectively.

\begin{tabular}{|c|c|c|c|c|c|c|c|c|}
\hline Compound & manufacturer & $\begin{array}{l}\mathrm{M} \\
(\mathrm{g} / \mathrm{mol})\end{array}$ & $\begin{array}{l}\text { density } \\
\left(\mathrm{g} / \mathrm{cm}^{3}\right)\end{array}$ & $\begin{array}{l}\text { conc. } \\
(\mathrm{g} / \mathrm{L})\end{array}$ & $\begin{array}{l}\mathrm{S} \\
(\%)\end{array}$ & $\begin{array}{l}\text { sol. }^{2} \\
\mathrm{H}_{2} \mathrm{O}\end{array}$ & $\begin{array}{l}\text { sol. }^{2} \\
\text { EtOH }\end{array}$ & $\begin{array}{l}\text { growth } \\
\text { EtOH }^{3}\end{array}$ \\
\hline $\mathrm{I}_{2} \mathrm{O}_{4}$ & selfmade 1,3 & 317.80 & $4.20^{2}$ & $\begin{array}{l}0.05 \\
0.002\end{array}$ & $\begin{array}{l}86 \\
84\end{array}$ & sl & $\mathrm{i}^{3}$ & no \\
\hline $\mathrm{I}_{2} \mathrm{O}_{5}$ & Merck & 333.80 & 4.98 & 0.01 & 86 & $\mathrm{~s}$ & $\mathrm{i}$ & no \\
\hline$\left(\mathrm{NH}_{4}\right)_{2} \mathrm{SO}_{4}$ & FF-Chemicals & 132.14 & 1.77 & 0.01 & 86 & vs & $\mathrm{i}$ & no \\
\hline$\left(\mathrm{NH}_{4}\right) \mathrm{HSO}_{4}$ & Fluka & 115.11 & 1.78 & 0.01 & 86 & vs & $\mathrm{i}$ & yes/no \\
\hline $\mathrm{NaCl}$ & FF-Chemicals & 58.44 & 2.17 & 0.01 & 86 & $\mathrm{~s}$ & sl & no \\
\hline $\begin{array}{l}\text { Citric } \\
\text { acid } \cdot \mathrm{H}_{2} \mathrm{O}\end{array}$ & $\begin{array}{l}\text { Fisher Chemi- } \\
\text { cals }\end{array}$ & 210.14 & 1.665 & 0.01 & 86 & vs & vs & yes \\
\hline Tartaric acid & Aldrich & 150.09 & 1.76 & 0.01 & 85 & $\mathrm{~s}$ & $\mathrm{~s}$ & yes \\
\hline
\end{tabular}

Table 2. The UFO-TDMA measured (Vaattovaara et al., 2005) ethanol growth factors (GF) of three individual compounds and a sulfuric acid mixture with ammonium bisulfate as a function of particle diameter at saturation ratio $85-86 \%$.

\begin{tabular}{ccccc}
\hline Size (nm) & $\begin{array}{c}\text { Tartaric acid } \\
\text { GF }\end{array}$ & $\begin{array}{c}\text { Citric acid } \\
\text { GF }\end{array}$ & $\begin{array}{c}\text { Ammonium bisulfate } \\
\text { GF }\end{array}$ & $\begin{array}{c}\text { Sulfuric acid } 18 \mathrm{~m} \% \\
\sim \text { GF }\end{array}$ \\
\hline 50 & 1.57 & 1.53 & 1.13 & 1.27 \\
30 & 1.48 & 1.46 & 1.06 & 1.13 \\
20 & 1.38 & 1.37 & 1.03 & 1.06 \\
10 & 1.08 & 1.16 & 0.98 & 1.00 \\
8 & 1.02 & 1.09 & - & - \\
6 & 1.01 & - & - & - \\
\hline
\end{tabular}

difference in peak channel positions for different size particles are best summarised in the Fig. 3a, where the peak channel location relative to the large-particle peak channel (usually 800th MCA channel) is plotted as a function of DMA mobility diameter.

The organic acids clearly have less separation from the $20 \mathrm{~nm}$ particles peak, while the inorganic species have significantly more separation. For example, pulses from the PHA-UCPC with the $3 \mathrm{~nm}$ size cis-pinonic acid particle are mainly located relative peak channel 0.9 (equivalent 720 th MCA channel), while the pulses from the $3 \mathrm{~nm}$ diameter $\mathrm{I}_{2} \mathrm{O}_{5}$ particles are measures at relative peak channel at 0.72 (equivalent to 560th MCA channel). Similarly, for channel width (Fig. 3b), the organic spectra are narrower than those resulting from the inorganic particles.

\subsection{Ancillary information}

Many types of additional information were available and used for aiding the UFO-TDMA and the PHA-UCPC measurement data-analysis. Thus, the presence of nucleation mode, Aitken mode, and bigger particles both particle concentration were detected from the University of Helsinki (by permission of P. P. Aalto) and Mace Head atmospheric research station DMPS (differential mobility particle sizer) data; air mass origin was solved based on the HYSPLIT (HYbrid Single-Particle Lagrangian Integrated Trajectory) model (Draxler and Rolph, 2003; Rolph 2003) back trajectory analysis, and cleanness of the air was examined from the research station BC (black carbon) data. Ocean chlorophyll a concentration and thus, ocean biological activity was checked by Sea-WiFS (Sea-viewing Wide Field-of-view Sensor) satellite data (NASA/Goddard Space Flight Center and ORBIMAGE); the station data for low tide times, wind direction and strength, solar radiation intensity, air pressure, and relative humidity were used to follow the local conditions. Further information about the station and its facilities are available in Jennings et al. (2003).

\section{Results and discussion}

\subsection{The UFO-TDMA field experiments}

The field experiments using the UFO-TDMA were carried out at the Mace Head station during a three weeks intensive 


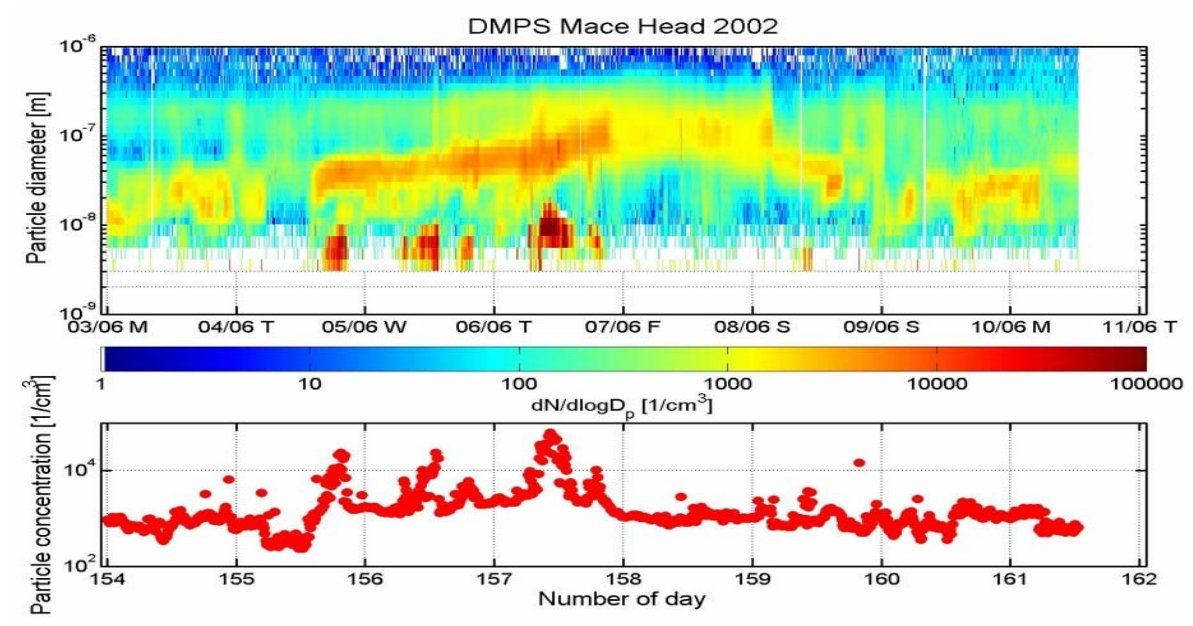

Fig. 4. The DMPS data presented (by permission of P. P. Aalto, University of Helsinki, Finland) with the particle size distribution and total number concentration as a function of time at Mace Head (days 3.6.2002-10.6.2002).

campaign (21 May 2002-10 June 2002, representing an enhanced biological activity period) in the framework of the European Union funded QUEST (Quantification of Aerosol Nucleation in the European Boundary Layer) project. The UFO-TDMA system was situated in a sea container on the rocky shore of the North Atlantic Ocean. The coastal biota is very rich with various types of macroalgae (green, brown, red), cyanobacteria and phytoplankton. Typically, clean marine air contains low $\mathrm{NO}_{\mathrm{x}}$ (i.e. $<30 \mathrm{ppt}$ of $\mathrm{NO}$ and $60-80 \mathrm{ppt}$ of $\mathrm{NO}_{2}$; Sommariva et al., 2006 and black carbon (BC) concentrations (i.e. $<50 \mathrm{ng} / \mathrm{m}^{3}$ ). Temperature, $R H$ (relative humidity) and air pressure were mainly between $284-290 \mathrm{~K}$, $70-90 \%$ and $970-1030 \mathrm{hPa}$, respectively, during this campaign and the nucleation events coincided mainly with daily temperature maxima and $R H$ minima. Temperature maxima and $R H$ minima have also been observed during the Pacific Ocean coastal events by Johnson et al. (2005).

Next, we will mainly focus on two of the strongest nucleation events observed during the campaign (coastal, low tide, sunlight, biologically active time) that occurred on 4 and 6 June. During those days, it was possible to follow the change of Aitken mode as well. The strength and length of the new particle formation events are seen for one week period in Fig. 4. The figure shows that during the strong events, the largest observed nucleation mode particles reach $10 \mathrm{~nm}$. Consequently, the measurements of sub $10 \mathrm{~nm}$ particles are especially important for characterizing newly-formed particles. In addition, as it is very likely that the source region is not very far from the measurement station (hundreds of meters to kilometers), the figure implies that the growth rates of the observed nucleation mode particles are quite high. Indeed, further evidence for quite high growth rates during the same QUEST campaign is given by O'Dowd et al. (2006) who made the airborne measurements of nucleation mode particle growth rates along the west coast of Ireland, in the vicinity of Mace Head. They found that close to coastal plume head $(<1 \mathrm{~km})$ growth rates can reach values as high as $123-171 \mathrm{~nm} \mathrm{~h}^{-1}$, decreasing gradually to $53-72 \mathrm{~nm} \mathrm{~h}^{-1}$ at $3 \mathrm{~km}$. Further along the plume, the growth rates were calculated to be $17-32 \mathrm{~nm} \mathrm{~h}^{-1}$ at $10 \mathrm{~km}$. Those growth rates are quite high compared to boreal forest cases, (see e.g. Kulmala et al., 2004a), but comparable to the earlier reported growth rates of $15-180 \mathrm{~nm} \mathrm{~h}^{-1}$ for recently formed nucleation mode particles at Mace Head (O'Dowd et al., 2002c and Dal Maso et al., 2002).

The main difference between 4 and 6 June events was that the 4 June event occurred with number concentration of $3 \times 10^{4} \mathrm{~cm}^{-3}$ during clean marine air mass (i.e. $100 \mathrm{~m}$ high trajectory) advected over multiple tidal zones (Fig. 5) with the BC mass concentration clearly below $50 \mathrm{ng} / \mathrm{m}^{3}$ and pre-existing particle concentration about $400 \mathrm{~cm}^{-3}$ in the evening whereas the 6 June event started at morning and ending at noon with number concentration of $9 \times 10^{4} \mathrm{~cm}^{-3}$ during moderate marine air mass advected over multiple tidal zones $10-20 \mathrm{~km}$ upwind of the measurements site (Fig. 6) with high $\mathrm{BC}$ mass concentration peaks and pre-existing particles number concentration about $4400 \mathrm{~cm}^{-3}$. Thus, 4 June is the cleaner case but solar radiation (UVR $\mathrm{Uff}$, i.e. erythermally, 340-300 nm, weighted ultraviolet (UV) A (wavelength $400-320 \mathrm{~nm}$ ) and UV B (wavelength about 320$280 \mathrm{~nm}$ ) radiation) was less intense (i.e. $\mathrm{UVR}_{\mathrm{eff}}$ from afternoon about $50 \mathrm{~W} / \mathrm{m}^{2}$ down to evening below $1 \mathrm{~W} / \mathrm{m}^{2}$ ) than the 6th $\left(\mathrm{UVR}_{\text {eff }}\right.$ from $50 \mathrm{~W} / \mathrm{m}^{2}$ during morning up to $130 \mathrm{~W} / \mathrm{m}^{2}$ during noon). The local wind direction was more effectively from the marine coastal region on 6 June.

On 4 June, the GFs of $6 \mathrm{~nm}$ particles were close to unity, indicating no growth as would be expected for iodine oxides, sulfate compounds, or organic compounds which are either ethanol insoluble or otherwise do not grow at the saturation ratio applied when the particle size is $6 \mathrm{~nm}$. Based on known 


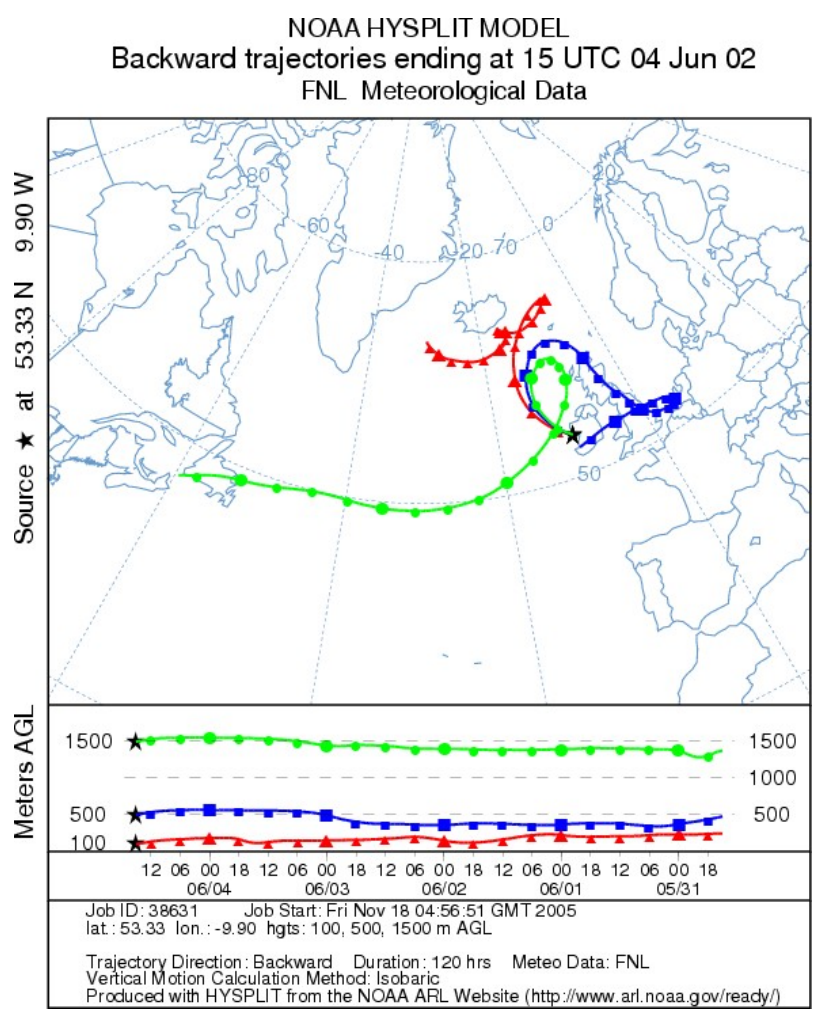

Fig. 5. HYSPLIT backward trajectories arriving to Mace Head site at 15:00 UTC (i.e. coordinated universal time) during the 4 June 2002.

information about coastal nucleation events, iodine oxides are likely constituents of the particles (O'Dowd et al., 1999; Mäkelä et al., 2002). However, we can not exclude an organic contribution. On 6 June, the $6 \mathrm{~nm}$ GFs were centered around 1.05 , which is a clear signature of the presence of organic species in the particles. The $8 \mathrm{~nm}$ growth factors behaved quite similarly as the $6 \mathrm{~nm}$ GFs. $10 \mathrm{~nm}$ growth factors (Fig. 7) indicate that on the 4th of June, at least some organic material was present in the particles, and that on the 6th, the organic signature (Fig. 8) is quite clear (i.e. GF 1.08). Interestingly, there seems to be an increasing trend in the $10 \mathrm{~nm}$ GFs on the 4th and 6th. Generally, however, comparison of different events and nucleation mode sizes with each other on the coastal region is unreliable, because different seaweed species grow at different depths from the sea level and in occasional rock pools, and produce iodine and organic compounds in different proportions, depending on the species and their distribution on the coastal area. Thus, local wind directions can have a major effect on the relative amounts of different compounds carried by the wind from the nearby marine biogenic sources. Furthermore, possible differences in the depth and time of low tide play a role for different macroalgae stress and solar radiation availability. Gas phase chemical composition and thus, photochemistry is also expected to be different between the morning, noon
NOAA HYSPLIT MODEL

Backward trajectories ending at 12 UTC 06 Jun 02

FNL Meteorological Data

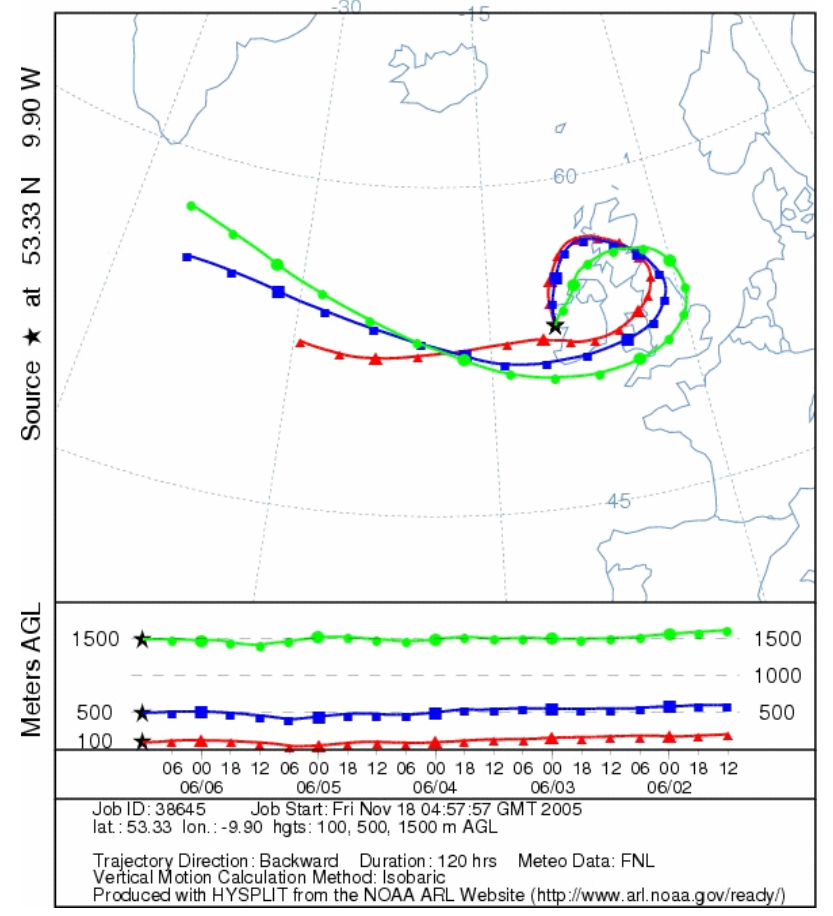

Fig. 6. HYSPLIT backward trajectories arriving to Mace Head site at 12:00 UTC (i.e. coordinated universal time) during the 6 June 2002 .

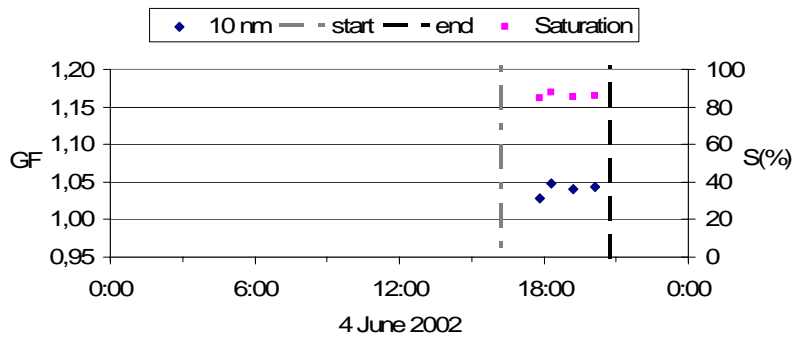

Fig. 7. The UFO-TDMA growth factors (GF) of $10 \mathrm{~nm}$ particles and saturation ratios $(\mathrm{S} \%)$ at about $86 \%$ measured as a function of time during evening new particle formation event 4.6.2002. The start and the end time of the event have been marked by vertical dashed lines.

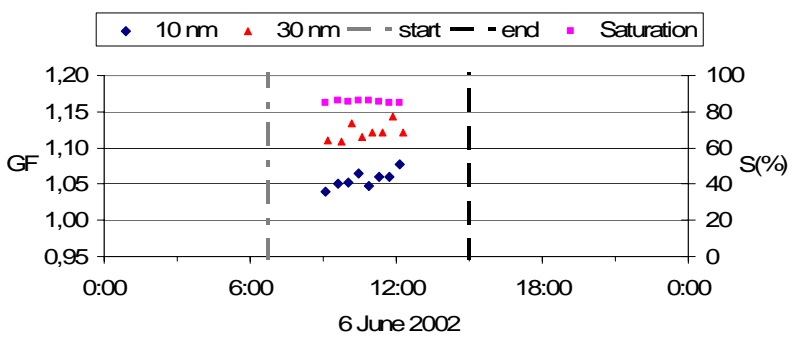

Fig. 8. The UFO-TDMA growth factors (GF) of $10 \mathrm{~nm}$ and $30 \mathrm{~nm}$ particles and saturation ratios $(\mathrm{S} \%)$ at about $86 \%$ measured as a function of time during noon new particle formation event 6.6.2002. The start and the end time of the event have been marked by vertical dashed lines. 
and evening events. Additionally, the GF uncertainties (i.e. $<0.02$ for $6-8 \mathrm{~nm}$ and $<0.01$ for $10-50 \mathrm{~nm}$; based on Vaattovaara et al., 2005) have an effect too.

Based on the presented event time GFs for $10 \mathrm{~nm}$ particles, a rough estimation of the organic volume fraction in the particles is possible. Assuming that the organic material is nonvolatile and very soluble in ethanol, an educated guess can be made that the GF for $10 \mathrm{~nm}$ particles composed of the organic material could be about 1.16, a similar number as we have measured in the laboratory for non-volatile and very ethanol soluble citric acid (which dissolves readily in ethanol). Assuming further that iodine oxides and the organic material do not interact during ethanol uptake, it can be calculated that the GF range 1.02-1.08 detected for $10 \mathrm{~nm}$ particles during nucleation events would correspond to organic volume fractions of $11-47 \%$. A somewhat higher GF of 1.2 for the pure organic material would yield organic volume fractions of 9$35 \%$. Our measured growth factors therefore show that in the $10 \mathrm{~nm}$ range, the organic contribution to the particles growth rate and survival probability is significant.

The DMPS data (Fig. 4) shows that the Aitken mode initially situated between about $20-50 \mathrm{~nm}$ grows to larger sizes (mode at about $100 \mathrm{~nm}$ ) during 4-6 June. Simultaneously, the total number concentration has an increasing trend. Furthermore, the UFO-TDMA data indicates that the composition of Aitken mode particles change at the same time (for example, GFs of $30 \mathrm{~nm}$ particles increase from about 1.11 toward 1.15 during the event of 6 June; Fig. 8). Unfortunately, the GFs of $50 \mathrm{~nm}$ particles were not measured during that episode. However, it is likely that $50 \mathrm{~nm}$ and particles behave similarly to $30 \mathrm{~nm}$ particles, because $30 \mathrm{~nm}$ and $50 \mathrm{~nm}$ particles are in the same mode; for example, on the event day 22 May, GF of $50 \mathrm{~nm}$ particles increased from 1.08 to 1.11 and GF of $20 \mathrm{~nm}$ increased from 1.08 to 1.13 at the same time. Interestingly, Väkevä et al. (2002) also noticed at Mace Head that $20 \mathrm{~nm}$ particles (UFH-TDMA, ultrafine hygroscopicity tandem differential analyzer, data) show similar characteristics of solubility compared with the $50 \mathrm{~nm}$ particles $(\mathrm{CCNC}$, cloud condensation nuclei counter, data). In this study, the GFs of the nucleation mode particles show that newly produced particles include a significant fraction of organic material. Because the same material can condense on the growing Aitken mode particles (Fig. 4), it is highly probable that the Aitken mode particles also contain secondary organic material.

Thus, secondary organic compounds produced during nucleation events are able to affect the potential $\mathrm{CCN}$ and the bigger, radiatively active particles at the coastal environment. Consequently, the sizes of the particles increase, and their composition and thermodynamic properties (e.g. surface tension, hygroscopicity, deliquescence behavior, potential to absorb semi-volatile organics) may change. Those properties (McFiggans et al., 2006) can have remarkable effects on the formation and properties of cloud droplets and clouds. Newly-formed secondary organic compounds which are sol- uble in both ethanol and water could decrease (compared to iodine oxide or ammonium sulfate) the surface tension of $\mathrm{CCN}$, increase (compared to iodine oxide or ammonium sulfate or water insoluble organic) their water absorption ability at relatively low $R H$ s (i.e. change their deliquescence behavior), and change the hygroscopicity of the $\mathrm{CCN}$ at high $\mathrm{RH}$ (direction and amount of the change depend on the nature and interactions of organic and inorganic compounds contained in the $\mathrm{CCN}$ ) and increase the potential of the $\mathrm{CCN}$ to absorb other kind of organic semi-volatile compounds. Indeed, CCN concentrations have been earlier observed to increase during a nucleation event at Mace Head site (O'Dowd, 2001). Also interestingly to this study, Aalto and Kulmala (2000) reported that $50 \mathrm{~nm}$ particles have $60 \%$ activation efficiency at $0.5 \%$ water supersaturation with a water soluble fraction of about 0.8 (compared to ammonium sulfate) in the marine air mass at the same site. Furthermore, Väkevä et al. (2002) used CCNC with $0.5 \%$ water supersaturation for particle diameters from $150 \mathrm{~nm}$ down to $15 \mathrm{~nm}$ (i.e. 150,112 , $84,63,47,35,27,20$, and $15 \mathrm{~nm}$ ) at Mace Head. The results show that with $0.5 \%$ water supersaturation the average ambient particles had to be eight nanometers larger than the ammonium sulfate particles used in the calibration in order to be activated. Thus, secondary organic compounds produced during the events have also important effects on properties of marine/coastal particle size distributions.

In order to further study the possibility that biogenic organics contribute to nucleation and Aitken modes particles mass, we also select the additional clean marine air mass day (27.5.02; Fig. 9) with new particle formation event during noon with number concentration of $5 \times 10^{5} \mathrm{~cm}^{-3}$ (Fig. 10) and very effective solar radiation $\left(\mathrm{UVR}_{\text {eff }}\right.$ from $150 \mathrm{~W} / \mathrm{m}^{2}$ down to $100 \mathrm{~W} / \mathrm{m}^{2}$ ). Furthermore, low BC mass concentration (i.e. $<50 \mathrm{ng} / \mathrm{m}^{3}$ ) and a low Aitken mode particle concentration with background number concentration below $1000 \mathrm{~cm}^{-3}$ were typical for clean marine air mass. The results indicate in $10 \mathrm{~nm}$ (Fig. 11) and $30 \mathrm{~nm}$ (Fig. 11) particles similar growth factors and trend as during the 6 June noon event, although this 27 May event lasts shorter time because wind direction turned from the coastal region including multiple tidal zones to more open sea direction. Consequently, although particle number concentration maximum during this very clean marine air mass event is as high as during the 6th event case, the concentration maximum lasts much shorter time. All that suggests that in addition to the 27 th and the 4th events also during the 6th event has marine/coastal biogenic secondary organic signature in the 6$10 \mathrm{~nm}$ particles. However, we cannot exclude the possibility that during 6 June moderate marine air mass event case the organic signature would be affected by condensation of anthropogenic secondary organic species as well.

Additionally, the open sea air mass trajectories (Fig. 9) and growth factors of $10 \mathrm{~nm}$ (Fig. 11) and $30 \mathrm{~nm}$ particles (Fig. 11) outside the event time of 27 May indicate that also open ocean biota produces organic compounds to nucleation 
NOAA HYSPLIT MODEL

Backward trajectories ending at 19 UTC 27 May 02 FNL Meteorological Data

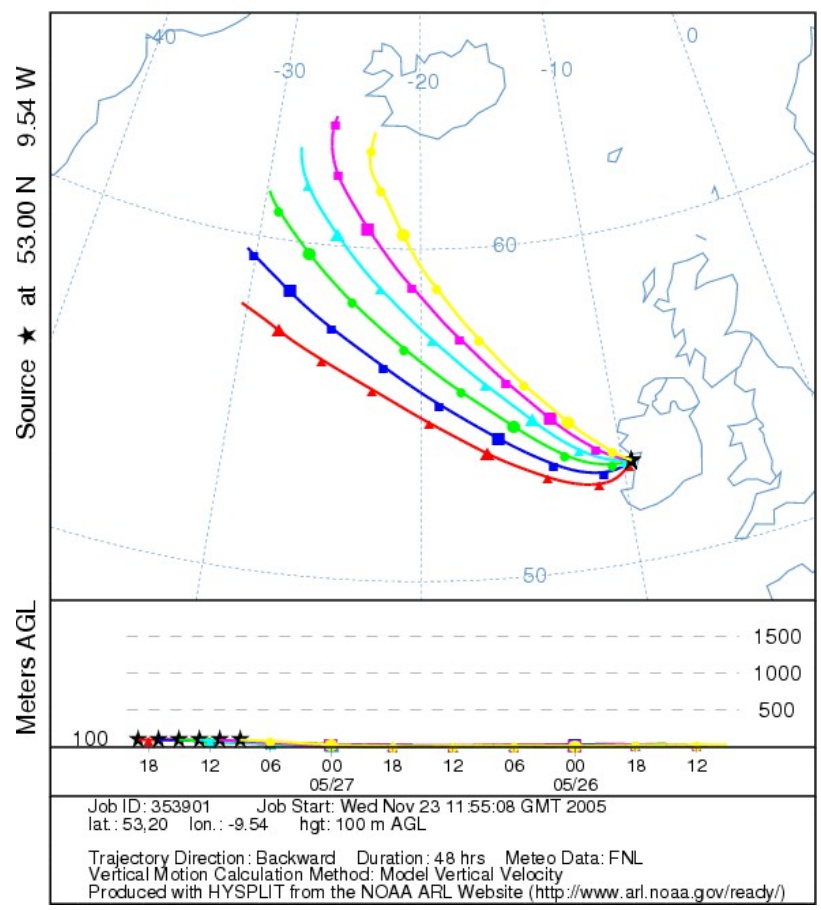

Fig. 9. HYSPLIT backward trajectories arriving to the Mace Head site at 9:00 (yellow), 11:00 (purple), 13:00 (turquoise), 15:00 (green), 17:00 (blue), and 19:00 (red) UTC (i.e. coordinated universal time), respectively, during 27 May 2002.

mode and lower Aitken mode sized particles. The same kind of phenomenon is detected also during other non-event open ocean cases/days (e.g. 30 May) with efficient solar radiation. That implies again biogenic secondary organic products, which can effect also on upper Aitken mode and bigger particles composition and properties.

\subsection{The PHA-UCPC field experiments}

For the PHA-UCPC data analysis, continuous measurements of aerosol size and total concentration were also conducted at the West coast of Ireland (Mace Head Atmospheric Research Station) where nucleation events have been reported usually along with low tide (O'Dowd et al., 2002a). Aerosol size distributions were measured using 2 SMPS (scanning mobility particle sizer) bank. The SMPS-I which consists of a nano-DMA (TSI model 3085) with an ultrafine CPC (TSI model 3025) measuring particle size distribution from $3.5 \mathrm{~nm}$ to $15 \mathrm{~nm}$ with a time resolution of $30 \mathrm{~s}$. The SMPS-II with a long-DMA (TSI model 3071) and a CPC (TSI model 3010) measures aerosol size distribution from 10 to $230 \mathrm{~nm}$ with a time resolution of $120 \mathrm{~s}$. The PHA-UCPC was also deployed, the sample air of which were needed to be diluted by 1:300
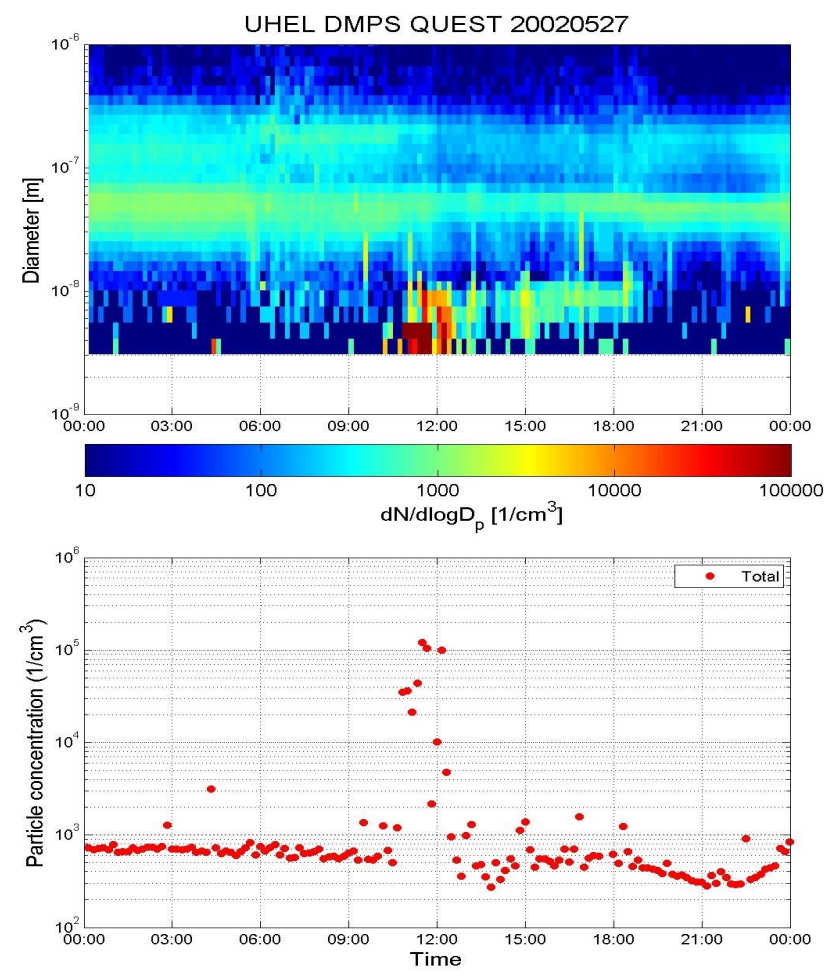

Fig. 10. The DMPS data presented (by permission of P. P. Aalto, University of Helsinki, Finland) with the particle size distribution and total number concentration as a function of time at Mace Head the 27 May 2002.

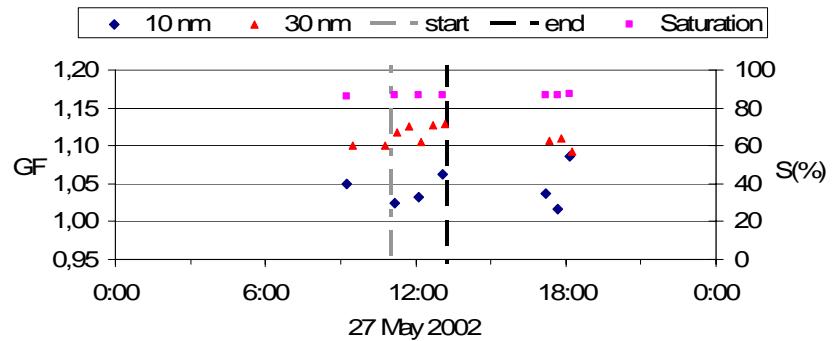

Fig. 11. The UFO-TDMA growth factors (GF) of $10 \mathrm{~nm}$ and $30 \mathrm{~nm}$ particles and saturation ratios $(\mathrm{S} \%)$ at about $86 \%$ measured as a function of time during the 27 May 2002 event. The start and the end time of the event have been marked by vertical dashed lines.

ratio because the concentrations of nucleation mode aerosol frequently reach up to $10^{6} \mathrm{~cm}^{-3}$ during nucleation events.

We chose a nucleation event at Mace Head when the origin of air mass arriving at the station was very clean marine condition (Day of Year (DOY) 281: 08 October 2002). Aerosol size distributions before, during, and after the event are shown in Fig. 12a. The aerosol concentration increased from $150-200 \mathrm{~cm}^{-3}$ to $500000 \mathrm{~cm}^{-3}$ in less than $30 \mathrm{~min}$. Figure 12a shows a huge increase in the concentration of particles smaller than $10 \mathrm{~nm}$ diameter with a modal diameter 


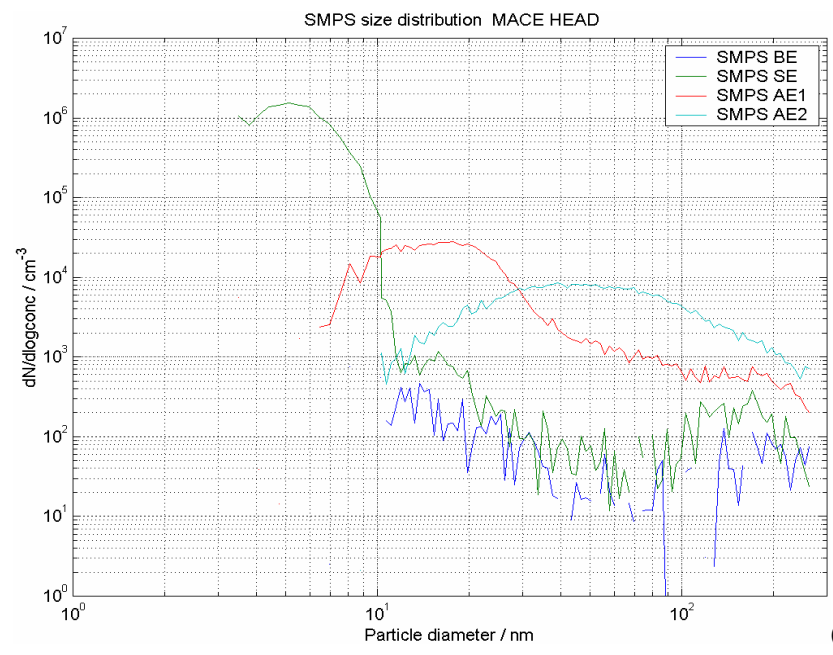

(a)

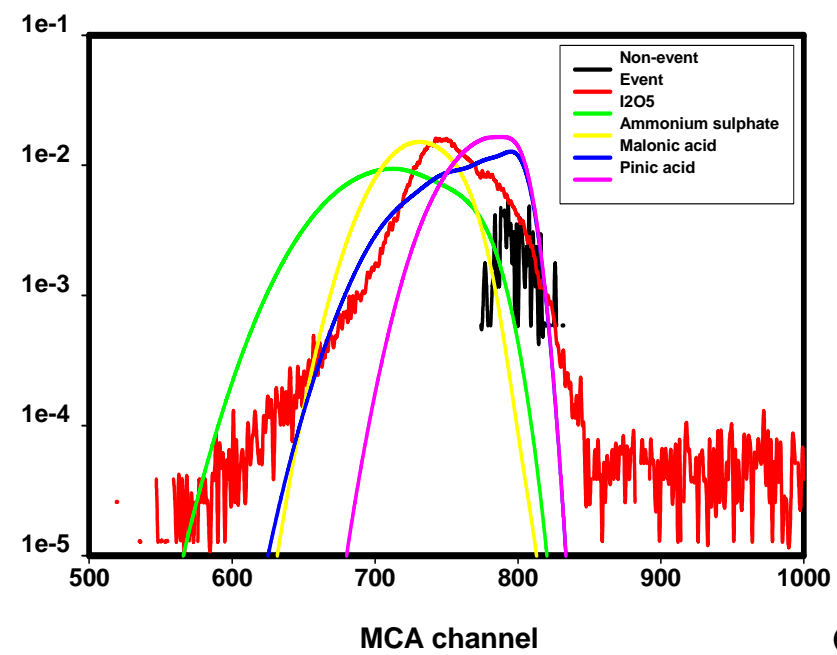

Fig. 12. (a) Aerosol size distribution at the Mace Head 8.10.2002 for (i) BE: before event (in blue), (ii) SE: starting event (in green), (iii) AE1: after event 1 (in red), and (iv) AE2: after event 2 (in sky blue). (b) Normalized pulse height distribution during nucleation event and calculated pulse height spectra by combining size distribution and laboratory calibration data. The non-event curve is for a typical non-event case.

located over 3-5 $\mathrm{nm}$ at the start of the event, while there was almost no change in the concentration of aerosols larger than $20 \mathrm{~nm}$ when compared with a background spectrum. The detected pulse height spectra for both before and after the nucleation event are shown in Fig. 12b. While the anchor channel (800th) still represents pulses from particles larger than $10 \mathrm{~nm}$, a greater number of small pulses were also detected during this nucleation event. As is clear from red line in the Fig. 12b, even the maximum pulse counting channel shifted from 800th to 725th, which means that pulses from nano-particles dominated throughout the PHA-UCPC channel. We calculated the pulse height distribution by combining measured SMPS aerosol size distribution with laboratory calibration data, and compared these simulated data against the in-situ measured pulse height distribution. The simulation was conducted with a laboratory calibration data-set of pinic acid, malonic acid, ammonium sulfate, and $\mathrm{I}_{2} \mathrm{O}_{5}$. The simulated and measured pulse height spectra are shown in Fig. 12b. Unlike boreal forests cases reported by O'Dowd et al. (2004a), pinic acid cannot re-simulate the measured pulse height alone at all. Calculated pulse height spectrum with malonic acid showed broader range of PHA-UCPC channel coverage but still this distribution cannot explain the peak channel at 725 th, nor the measured shoulder of pulse heights. Ammonium sulfate showed a better agreement for the peak channel, but failed to simulate the small pulses from 3-4 nm diameter particles, which locate between 500th and 600th PHA-UCPC channel. Simulations with $\mathrm{I}_{2} \mathrm{O}_{5}$ can explain small pulses from $3-4 \mathrm{~nm}$ particles, but cannot represent pulses for 7-8 nm particles.

It is most likely that the composition of particles with diameter 3 to $4 \mathrm{~nm}$ are mainly dominated by iodine compounds, as ammonium sulfate can not explain small pulses and these nanoparticles are insoluble in the PHA-UCPC butanol chamber. When the nano-particles grow by condensation or coagulation, it seems that the chemical composition becomes somewhat a mixture of complex species, at least which can not be explained by only one of the species for which we made a laboratory calibration.

It can be inferred from our simulation that $3-4 \mathrm{~nm}$ particle nucleation is mainly affected or triggered by iodine compounds and as this aerosol grows ammonium sulfate or some unidentified organic species may also contribute to the composition at the coastal environment. However, based on earlier known information about the sulfate compounds (Väkevä et al., 2002) and considering that the UFO-TDMA results above strongly indicate an organic contribution in particles larger than $6 \mathrm{~nm}$, the organic type explanation of the PHAUCPC data seems more likely, even though sulfate compounds are probably present in small amounts as well.

\subsection{Origin and fate of marine secondary organic com- pounds}

Even though the Mace Head area is free of woodlands and monoterpenes or sesqiterpenes have not been observed in the coastal region (Sartin et al., 2001), there is plenty of evidence about biogenic coastal organic sources during daylight hours at Mace Head: Because of the abundant marine biota of that coastal region, a remarkable amount of isoprene and other organic compounds are produced by the coastal seawater and marine biota (production from seawater and marine biota can be associated with biological processes of marine phytoplankton and cyanobacteria and is dependent of light, temperature, and organism size (Shaw et al., 2003); and particularly with biological processes of inter-tidal seaweeds (Sartin et al., 2002; Broadgate et al., 2004), whose biological production is related to light availability and temperature and 
is species dependent (Broadgate et al., 2004)). Furthermore, the concentrations of isoprene and other short-lived alkenes produced from the local coastal waters, have been observed to show maximum atmospheric levels during daylight and to be responsible for up to $88 \%$ of non-methane hydrocarbon (NMHC) reactions with the hydroxyl radical at that coastal marine site (Lewis et al., 1999), showing the importance of the role of alkenes in the Mace Head boundary layer chemistry. Also, Lewis et al. (1997) and Carslaw et al. (2000) emphasized the significance of isoprene reactions and thus their oxidation products in the coastal daylight chemistry. At the same coastal site, Fowler et al. (1997) reported that isoprene normally has a clear diurnal cycle with maximum concentrations appearing after solar noon due to biogenic emission fluxes being strongly influenced by temperature and net photosynthetically active radiation (PAR).

As a very relevant example of oxidation products of the biosynthetically produced important and very reactive organic gases of coastal and marine origin, isoprene oxidation products have been found in the particle phase from various terrestrial biogenic source regions (from a Japanese mixed forest by Matsunaga et al., 2003; from the Amazon rain forest in the Brazil by Clayes et al., 2004; and from a Finnish boreal forest by Kourtchev et al., 2005). Furthermore, SOA (secondary organic aerosol) formation capability of isoprene in the presence of a seed aerosol has been shown in the laboratory study of Limbeck et al. (2003), in the smog chamber study of Jang et al. (2002), in the indoor chamber studies of Nga et al. (2006), Lee et al. (2006) and Surratt et al. (2006), and in the aerosol chamber and field study of Böge et al. (2006), for example.

Similarly to coastal nucleation events, the increase of isoprene production from different coastal seaweeds (red, brown, green) has been related to stress due to low tide with estimated isoprene flux from seaweeds up to $6.8 \times 10^{8}$ molecules $\mathrm{cm}^{-2} \mathrm{~s}^{-1}$ at the Mace $\mathrm{Head}$ coast (Broadgate et al., 2004). Similar flux values $\left(8.8 \times 10^{8}\right.$ molecules $\left.\mathrm{cm}^{-2} \mathrm{~s}^{-1}\right)$ were estimated at a nearby site by Greenberg et al. (2005). They also measured isoprene air concentrations of 10-160 ppt (median $68 \mathrm{ppt}$ ), 7-210 ppt (median $63 \mathrm{ppt}$ ), and 7-270 ppt (median $41 \mathrm{ppt}$ ) at altitudes of $0 \mathrm{~m}, 50 \mathrm{~m}$, and $100 \mathrm{~m}$, respectively, at the coast $5 \mathrm{~km}$ away from Mace Head. Corresponding high and even higher (up to $350 \mathrm{ppt}$ ) isoprene concentrations have frequently been detected from biogenic local sources at the Mace Head coast during daytime (e.g. Carslaw et al., 2000; Heard et al., 2006), especially in summer. Isoprene concentrations are also at least comparable with iodine gas (i.e. $\mathrm{I}_{2}$ ) concentrations measured during low tide at a nearby location (20-100 ppt; Sellegri et al., 2005) and the Mace Head site (10 ppt; Saiz-Lopez and Plane, 2004).

Reaction products of isoprene atmospheric oxidation mechanisms initiated by $\mathrm{OH}, \mathrm{O}_{3}, \mathrm{NO}_{3}$, and a halogen radical $\left(\mathrm{Cl}^{-}\right)$, recently described by Fan and Zhang (2004), also support the potential of SOA formation. It is worth of noticing that the coastally important iodine belongs to the same reactive halogen group as chlorine. Therefore, iodine radical reactions with the coastal alkenes like isoprene are able to initiate oxidation process. Furthermore, because $\mathrm{Cl}$-isoprene reaction rate constant $\left(4.27 \times 10^{-10} \mathrm{~cm}^{3}\right.$ molecule ${ }^{-1} \mathrm{~s}^{-1}$; Fan and Zhang, 2005) is considerably faster than the reactions of isoprene with hydroxyl radical $\left(9.98 \times 10^{-11} \mathrm{~cm}^{3}\right.$ molecule $\mathrm{e}^{-1} \mathrm{~s}^{-1}$; Atkinson, 1986), also iodine could be expected to accelerate isoprene oxidation. Also the presence of organic iodine compounds in marine aerosol has already been shown and the importance suggested (e.g. Baker, 2005). Even though chlorine and also bromine halocarbons are produced coastally during low tide at Mace Head (Carpenter et al., 1999), their photolysis is expected to occur on a much longer timescale than that of equivalent alkyl iodides (Carpenter et al., 1999) and thus, the longer-lived chlorine and bromine compounds are not expected to take very effectively part in new particle formation. Also, a comparison between coastally observed $\mathrm{BrO}$ and $\mathrm{IO}$ rate coefficients with $\mathrm{HO}_{2}$ indicates that iodine is the more important one of those two oxides in the marine boundary layer chemistry. Most importantly for nucleation mode particle phase, Mäkelä et al. (2002) did observe a lot of iodine but no chlorine nor bromine in their TEM samples during the coastal events. Actually, iodine-isoprene reactions are very probable on the coastal site with brown algae (e.g. Laminaria digitata and Fucus vesiculosus) which produce both iodine gas and isoprene. Moreover, some of common red and green algae species which can grow nearby brown algae species are much more effective isoprene producers than brown algae (Broadgate et al., 2004).

Additionally, contrary to brown algae (e.g. Laminaria saccharina), red and green algae are known (Malin and Kirst, 1997) to be able to produce also DMS (i.e. $\mathrm{CH}_{3} \mathrm{SCH}_{3}$ ) as a by-product of the production of a reactive alkene (i.e. acrylic acid, $\mathrm{C}_{3} \mathrm{H}_{4} \mathrm{O}_{2}$; Van Alstyne and Houser, 2003). Biogenic production of sulfuric acid also detected from red and green algae or/and planktonic algae at the Mace Head coast can have an import role in catalysis of organic reactions, thus accelerating their oxidation rate in addition to possible forming thermodynamically stable clusters (TSC) taking part in new particle formation events. Moreover, at marine coast region important isoprene is very soluble in ethanol (CRC Handbook of Chemistry and Physics, 2005) and thus, its oxidation products are expected to grow in sub saturated ethanol vapor. It is also worth of noticing that $10 \mathrm{~nm}$ tartaric acid particles do grow in sub saturated ethanol vapor and show the GF of 1.08 at saturation ratio $85-86 \%$ (see Table 2).

Thus, when we take into account the high amount of isoprene which is biosynthetically produced by marine phytoplankton (Shaw et al., 2003) and seaweeds (Broadgate et al., 2004) during efficient solar radiation and low tide in the same locations as the high number concentration of iodine radicals, isoprene reactivity with halogen radicals, hydroxyl radicals and ozone, and isoprene formation capability of different 


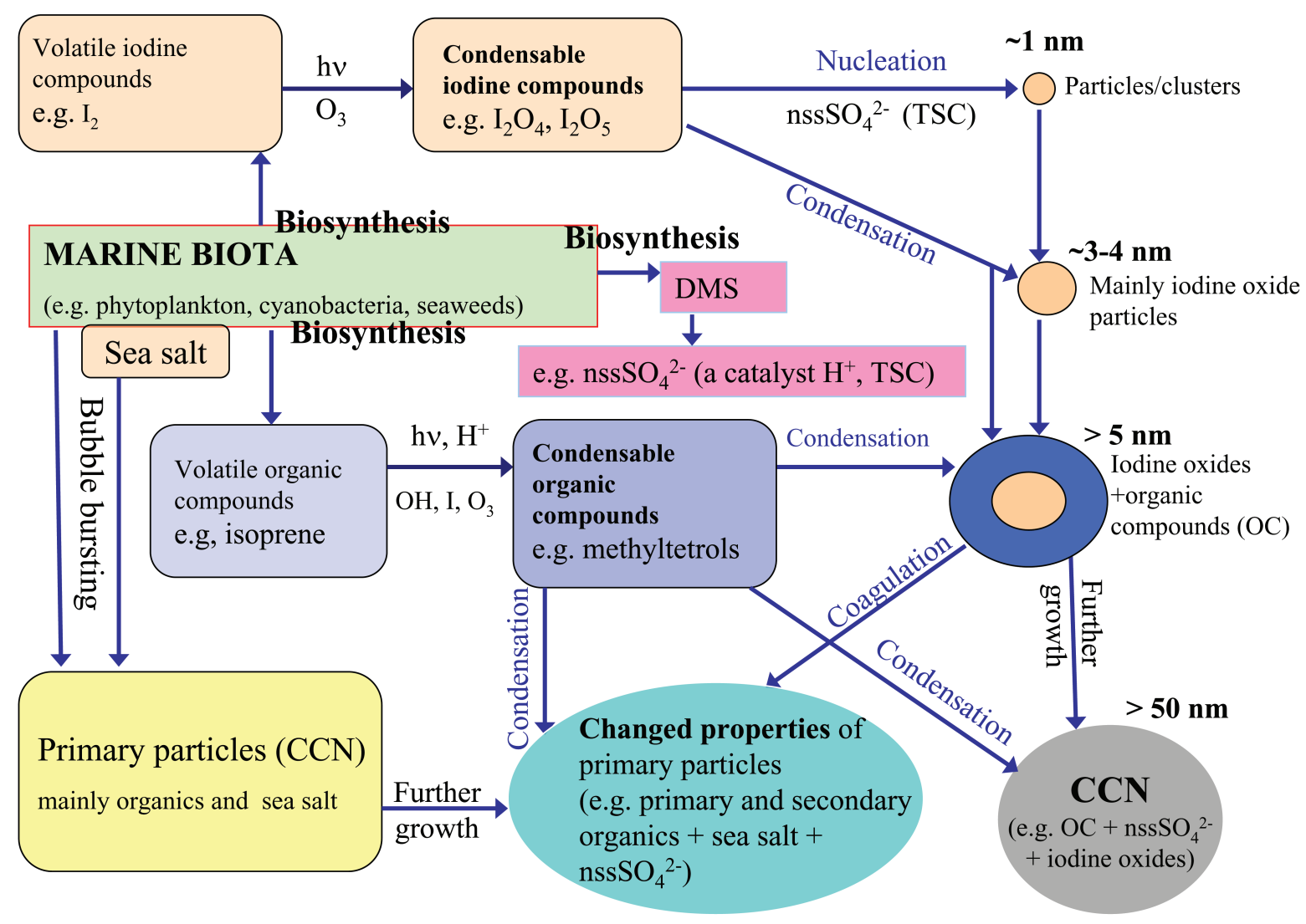

Fig. 13. The rough outlook about biogenic nucleation and Aitken modes particles formation, growth, and composition during daylight at the background coastal/marine region.

oxidation products, it is very probable that oxidation products of biogenic alkenes significantly contribute to the organics detected in the particles.

Also for open ocean cases, a natural explanation for the presence of organic fraction in the nucleation and the lower end of Aitken modes particles would be oxidation products of organics such as isoprene (see Lewis et al., 1999), produced by marine phytoplankton and cyanobacteria (Shaw et al., 2003) during coastal non-event time (i.e. no low tide, no nucleation event, but efficient solar radiation). Particle number concentration of very clean marine air mass is low compared to the coastal event time particle number concentration. The comparison of the estimated fluxes of 6-7 $\times 10^{8}$ isoprene molecules $\mathrm{cm}^{-2} \mathrm{~s}^{-1}$ from the local coastal macroalgae (Broadgate et al., 2004) and about 3-6 $\times 10^{7}$ isoprene molecules $\mathrm{cm}^{-2} \mathrm{~s}^{-1}$ from marine phytoplankton during East Atlantic bloom (Shaw et al., 2003) reveals that quantitative contribution of open ocean origin isoprene oxidation products would seem to be more or less minor compared to high particle number concentration coastal events. However, the open ocean origin secondary organics can play an important role in different sized particles composition and properties on the open ocean area because of possible long lasting organic precursor gas production over large ocean surface.

Figure 13 summarizes the rough overall outlook that has emerged from the biogenic coastal/marine nucleation and Aitken modes particles formation, growth, and composition at the Mace Head region.

\section{Conclusions}

In this study, we applied the UFO-TDMA method to shed light on the presence of organics in newly-formed nucleation mode particles at a coastal site in West Ireland (Mace Head). The focus was on typical coastal nucleation events which occurred at low tide conditions during efficient solar radiation and enhanced biological activity at spring 2002 . The results indicate that coastally formed nucleation mode particles include a significant fraction of secondary organic products, beside iodine oxides which have earlier been identified as constituents of the newly-formed particles. Based on this study and literature information published so far, the origin of those secondary organic oxidation compounds can be related to marine coast and open ocean biogenic sources (i.e. phytoplankton, cyanobacteria, and especially 
various seaweeds) and thus mainly biosynthetic production of alkenes like isoprene and their oxidation driven by hydroxyl radicals, ozone, biogenic iodine radicals, and acid catalysis during efficient solar radiation. Furthermore, during nucleation event in pollution influenced modified marine air mass, also anthropogenic secondary organic compounds can have an effect to the nucleation mode particles.

Additionally, our UFO-TDMA results suggest that biogenic secondary organic compounds originating from marine coast and open ocean biota may, in addition to being significant contributors to the nucleation mode processes, affect the formation (i.e. size, composition and thus, variety of properties) of CCN and even larger radiatively active particles (e.g. those produced by bubble bursting), subsequently playing an important role at least in the regional radiative budget, influencing also different feedback mechanisms between marine coast and open ocean biota, aerosols, clouds, and solar radiation.

Furthermore, the PHA-UCPC technique was used to study the composition of newly-formed particles during the LBA period in October, at the same coastal location. Overall, the PHA-UCPC observations seem to be in agreement with the current knowledge about the presence of iodine oxides in the smallest newly-formed coastal particles. On the other hand, the spectra for somewhat larger, 7-8 $\mathrm{nm}$ particles cannot be explained by iodine oxides alone, and considering the fact that the amount of sulfate in the particles is likely to be minor, an organic contribution seems to be the most reasonable explanation. The PHA-UCPC measurement described in this study was also conducted during inflow of clean marine air mass, and therefore isoprene is a likely precursor of the detected organic signal.

Taken together, the nucleation mode measurements presented in this paper suggest that iodine oxides are mainly responsible for the nucleation and early growth of newlyformed coastal particles, and that condensable secondary organics start more effectively to contribute to the growth at particle sizes of about $5-6 \mathrm{~nm}$. It is possible that the large Kelvin effect prevents the condensation of the organics at smaller particle sizes (Kulmala et al., 2004b), suggesting interestingly the idea that produced organic oxidation products would need a seed for secondary organic aerosol formation.

A future plan is to perform laboratory/chamber experiments, using the UFO-TDMA, employing particles composed of coastally/marinely important iodine compounds and isoprene oxidation products in order to quantify in more details the secondary organic effects detected in the nucleation mode. Additional in situ measurements need also to be carried out in order to gain insight into the diurnal composition behavior of the nucleation and Aitken modes particles originating from the coastal and open ocean regions.

From the wider perspective, biogenically driven secondary organic contributions can be anticipated also at other biologically active, species specific marine coast and open sea waters (covering parts of all five oceans, especially at temperate and polar zones; see Fig. 1c and compare with Kulmala et al., 2004a). It is worth of noticing that the surface of biologically active marine coast and open ocean regions is really large. Furthermore, similar effects could also be possible in fresh waters (e.g. lakes; see Fig. 1c). Thus, from the global perspective of particle and CCN formation and their climatically important properties, it would be crucial to experimentally investigate biogenic secondary organic contributions at those biosynthetically active ocean areas and fresh waters located around the world.

Acknowledgements. This work was supported by EU (European Union) 5th Framework Programme through the QUEST (Quantification of Aerosol Nucleation in the European Boundary Layer) project, Emil Aaltonen Foundation, Academy of Finland project 52476, and Academy of Finland through the Center of Excellence programme. We wish to thank the staff of University of Helsinki (Finland) and National University of Ireland (Galway, Ireland) about great helpfulness and support during the QUEST campaign. Especially, we thank P. P. Aalto for the pictures of DMPS data, S. Cheevers and C. Kleefeld for help with meteorological data, and B. Kelly for delivering black carbon data. The authors also gratefully acknowledge SeaWiFS project (NASA/Goddard Space Flight Center and ORBIMAGE) for satellite pictures and the NOAA Air Resources Laboratory (ARL) for the provision of the HYSPLIT transport and dispersion model and READY website (http://www.arl.noaa.gov/ready.html) used in this publication.

Edited by: K. Hämeri

\section{References}

Aalto, P. P. and Kulmala, M.: Using a cloud condensation nuclei counter to study CCN properties and concentrations, Boreal Environ. Res., 5, 349-359, 2000.

Alfonso, L. and Raga, B.: The influence of organic compounds on the development of precipitation acidity in maritime clouds, Atmos. Chem. Phys., 4, 1097-1111, 2004,

http://www.atmos-chem-phys.net/4/1097/2004/.

Andreae, M. O. and Crutzen, P. J.: Atmospheric aerosols: Biogeochemical sources and role in atmospheric chemistry, Science, 276, 1052-1058, 1997.

Atkinson, R.: Kinetics and mechanisms of the gas-phase reactions of the hydroxyl radical with organic compounds under atmospheric conditions, Chem., Rev., 86, 69-201, 1986.

Baker, A. R.: Marine aerosol iodine chemistry: the importance of soluble organic iodine, Environ. Chem., 2, 295-298, 2005.

Böge, O., Miao, Y., Plewka, A., and Herrmann, H.: Formation of secondary organic particle phase compounds from isoprene gasphase oxidation products: An aerosol chamber and field study, Atmos. Environ., 40, 2501-2509, 2006.

Broadgate, W. J., Malin, G., Küpper, F.C., Thompson, A., and Liss, P. S.: Isoprene and other non-methane hydrocarbons from seaweeds: a source of reactive hydrocarbons to the atmosphere, Mar. Chem., 88, 61-73, 2004.

Burkholder, J. B., Curtius, J., Ravishankara, A. R., and Lovejoy, E. R.: Laboratory studies of the homogeneous nucleation of iodine 
oxides, Atmos. Chem. Phys., 4, 19-34, 2003,

http://www.atmos-chem-phys.net/4/19/2003/.

Carpenter, L. J., Sturges, W. T., Penkett, S. A., Liss, P. S., Alicke, B., Hebestreit, K., and Platt, U.: Short-lived alkyl iodides and bromides at Mace Head, Ireland: Link to biogenic sources and halogen oxide production, J. Geophys. Res., 104(D1), 1679-1689, 1999.

Carslaw, N., Bell, N., Lewis, A. C., McQuaid, J. B., and Pilling, M. J.: A detailed case study of isoprene chemistry during the EASE96 Mace Head campaign, Atmos. Environ., 34, 28272836, 2000.

Clayes, M., Graham, B., Vas, G., Wang, W., Vermeylen, R., Pashynska, V., Cafmeyer, J., Guyon, P., Andreae, M. O., Artaxo, P., and Maenhaut, W.: Formation of secondary organic aerosols through photooxidation of isoprene, Science, 303, 1173-1176, 2004.

CRC Handbook of Chemistry and Physics, 77th edition, CRC press, 1996.

CRC Handbook of Chemistry and Physics, 86th edition, CRC press, 2005.

Creac'h, P. V.: Presence of citric and malic acids in littoral marine waters, Hebd. Seances Acad. Sci., 240, 2551-2553, 1955.

Daehlie, G. and Kjekshus, A.: Iodine oxides, Part I., Acta Chem. Scand., 18, 144-156, 1964.

Dal Maso, M., Kulmala, M., Lehtinen, K. E. J., Mäkelä, J. M., Aalto, P., and O'Dowd, C. D.: Condensation, and coagulation sinks and formation of nucleation mode particles in coastal and boreal forest boundary layers, J. Geophys. Res., 107(D19), doi:10.1029/2001JD001053, 2002.

DeBolt, S., Cook, D. R., and Ford, C. M.: L-Tartaric acid synthesis from vitamin $\mathrm{C}$ in higher plants, PNAS, 103, 14, 5608-5613, 2006.

Draxler, R. R. and Rolph, G. D.: HYSPLIT (HYbrid Single-Particle Lagrangian Integrated Trajectory) Model access via NOAA ARL READY Website: http://www.arl.noaa.gov/ready/hysplit4.html, NOAA Air Resources Laboratory, Silver Spring, MD, 2003.

Fan, J. and Zhang, R.: Atmospheric oxidation mechanism of isoprene, Environ. Chem., 1, 140-149, 2004.

Fowler, D., Coyle, M., Anderson, R., Ashmore, M. R., Bower, J. S., Burgess, R. A., Cape, J. N., Cox, R. A., Derwent, R. G., Dollard, G. J., Grennfelt, P., Harrison, R. M., Hewitt, C. N., Hov, Ø., Jenkin, M. E., Lee, D. S., Maynard, R. L., Penkett, S. A., Smith, R. I, Stedman, J. R., Weston, K. J., Williams, M. L., and Woods, P. J.: Ozone in the United Kingdom, Fourth report of the photochemical oxidants review group, 1997.

Greenberg, J. P., Gunther, A. B., and Turnipseed, A.: Marine organic halide and isoprene emissions near Mace Head, Ireland, Environ.Chem., 2, 291-294, 2005.

Heard, D. E., Read, K. A., Methven, J., Al-Haider, S., Bloss, W. J., Johnson, G. P., Pilling, M. J., Seakings, P. W., Smith, S. C., Sommariva, R., Stanton, J. C., Still, T. J., Ingham, T., Brooks, B., De Leeuw, G., Jackson, A. V., McQuaid, J. B., Morgan, R., Smith, M. H., Carpenter, L. J., Carslaw, N., Hamilton, J., Hopkins, J. R., Lee, J. D., Lewis, A. C., Purvis, R. M., Wevill, D. J., Brough, N., Green, T., Mills, G., Penkett, S. A., Plane, J. M. C., Saiz-Lopez, A., Worton, D., Monks, P. S., Fleming, Z., Richard, A. R., Alfarra, M., Allan, J. D., Bower, K., Coe, H., Cubison, M., Flynn, M., McFiggans, G., Gallagher, M., Norton, E. G., O'Dowd, C. D., Shillito, J., Topping, D., Vaughan, G., Williams, P., Bitter, M., Ball, S. M., Jones, R. L., Povey, I. M., O'Doherty,
S., Simmonds, P. G., Allen, A. Kinnersley, R. P., Beddows, D. C. S., Dall'Osto, M., Harrison, R. M., Donovan, R. J., Heal, M. R., Jennings, S. G., Noone, C., and Spain, G.: The North Atlantic marine boundary layer experiment (NAMBLEX). Overview of the campaign held at Mace Head, Ireland, in summer 2002, Atmos. Chem. Phys., 6, 2241-2272, 2006,

http://www.atmos-chem-phys.net/6/2241/2006/.

Hoffmann, T., O’Dowd, C. D., and Seinfeld, J. H.: Iodine oxides and new particle formation, Geophys. Res. Lett., 28, 1949-1952, 2001.

Jang, M. S., Czoschke, N. M., Lee, S., and Kamens, R. M.: Heterogeneous atmospheric aerosol production by acid-catalyzed particle-phase reactions, Science, 298, 814-817, 2002.

Jennings, S. G., Kleefeld, C., O’Dowd, C. D., Junker, C., Spain, T. G., O'Brien, P., Aodhaghan, F. R., and O'Connor, T. C.: Mace Head Atmospheric Research Station - characterization of aerosol radiative parameters, Boreal Env. Res., 8, 303-314, 2003.

Jimenez, J. L., Bahreini, R., Cocker, D. R., Zhuang, H., Varutbangkul, V., Flagan, R. C., Seinfeld, J. H., O’Dowd, C. D., and Hoffmann, T.: New particle formation from photooxidation of diiodomethane $\left(\mathrm{CH}_{2} \mathrm{I}_{2}\right)$, J. Geophys. Res., 108(D10), 4318, doi:10.1029/2002JD002452, 2003.

Johnson, G. R., Ristovski, Z. D., D’Anna, B., and Morawska, L.: Hygroscopic behavior of partially volatilized coastal marine aerosols using the volatilazation and humidification tandem differential mobility analyzer technique, J. Geophys. Res., 110, D20203, doi:10.1029/2004JD005657, 2005.

Joutsensaari, J., Vaattovaara, P., Vesterinen, M., Hämeri, K., and Laaksonen, A.: A novel tandem differential mobility analyzer with organic vapor treatment of aerosol particles, Atmos. Chem. Phys., 1, 51-60, 2001, http://www.atmos-chem-phys.net/1/51/2001/.

Kourtchev, I., Ruuskanen, T., Maenhaut, W., Kulmala, M., and Clayes, M.: Observation of 2-methyltetrols and related photooxidation products of isoprene in boreal forest aerosols from Hyytiälä, Finland, Atmos. Chem. Phys., 5, 2761-2770, 2005, http://www.atmos-chem-phys.net/5/2761/2005/.

Kulmala, M., Vehkamäki, H., Petäjä, T., Dal Maso, M., Lauri, A., Kerminen, V.-M., Birmili, W., and McMurry, P. H.: Formation and growth rates of ultrafine atmospheric particles: a review of observations, J. Aerosol. Sci., 35, 143-176, 2004a.

Kulmala, M., Kerminen, V.-M., Anttila, T., Laaksonen, A., and O'Dowd, C. D.: Organic aerosol formation via sulphate cluster activation, J. Geophys. Res., 109, D04205, doi:10.1029/2003JD003961, 2004b.

Lee, A., Goldstein, A. L., Kroll, J. H., Nga, L. Ng., Varutbangkul, V., Flagan, R. C., and Seinfeld, J. H.: Gas-phase products and secondary aerosol yields from the photooxidation of 16 different terpenes, J. Geophys. Res., 111, D05302, doi:10.1029/2006JD007050, 2006.

Lewis, A. C., Bartle, K. D., Heard, D. E., McQuaid, J. B., Pilling, M. J., and Seakins, P. W.: In situ, gas chromatographic measurements of non-methane hydrocarbons and dimethyl sulfide at a remote coastal location (Mace Head, Eire) July-August 1996, J. Chem. Soc., Faraday Trans., 93(17), 2921-2927, 1997.

Lewis, A. C., McQuaid, J. B., Carslaw, N., and Pilling, M. J.: Diurnal cycles of short-lived tropospheric alkenes at a north Atlantic coastal site, Atmos. Environ., 33, 2417-2422, 1999.

Limbeck, A., Kulmala, M., and Puxbaum, H.: Secondary organic 
aerosol formation in the atmosphere via heterogeneous reaction of gaseous isoprene on acidic particles, Geophys. Res. Lett., 30(19), 1996, doi:10.1029/2003GL017738, 2003.

Mäkelä, J. M., Hoffmann, T., Holzke, C., Väkevä, M., Suni, T., Mattila, T., Aalto, P., Tapper, U., Kauppinen, E., and O’Dowd, C. D.: Biogenic iodine emissions and identification of end-products in coastal ultarafine particles during nucleation bursts, J. Geophys. Res., 107(D19), 8110, doi:10.1029/2002JD002132, 2002.

Malin, G. and Kirst G. O.: Algal production of dimethylsulfide and its atmosphere role, J. Phycol., 33, 889-896, 1997.

Matsunaga, S., Mochida, M., and Kawamura, K.: Growth of organic aerosols by biogenic semi-volatile carbonyls in the forestal atmosphere, Atmos. Environ., 37, 2045-2050, 2003.

McFiggans, G., Coe, H., Burgess, R., Allan, J., Cubison, M., Alfarra, M. R., Saunders, R., Saiz-Lopez, A., Plane, J. M. C., Wevill, D., Carpenter, L., Rickard, A. R., and Monks, P. S.: Direct evidence for coastal iodine particles from Laminaria macroalgae - linkage to emissions of molecular iodine, Atmos. Chem. Phys., 4, 701-713, 2004,

http://www.atmos-chem-phys.net/4/701/2004/.

McFiggans, G., Artaxo, P., Baltensberger, U., Coe, H., Facchini, M. C., Feinfold, G., Fuzzi, S., Gysel, M., Laaksonen, A., Lohmann, U., Mentel, T. F., Murphy, D. M., O'Dowd, C. D., Snider, J. R., and Weingartner, E.: The effect of physical and chemical aerosol properties on warm cloud droplet activation, Atmos. Chem. Phys., 6, 2593-2649, 2006,

http://www.atmos-chem-phys.net/6/2593/2006/.

Mertes, S., Schröder, F., and Wiedensohler, A.: The particle detection efficiency curve of the TSI-3010 CPC as a function of temperature difference between saturator and condenser, Aerosol Sci. Technol., 23, 257-261, 1995.

Ming, Y. and Russell, L.: Predicted hygroscopic growth of sea salt aerosol, J. Geophys. Res., 106, 28 259-28 274, 2001.

Nga, L. Ng., Kroll, J. H., Keywood, M. D., Bahreini, R., Varutbangkul, V., Flagan, R. C., and Seinfeld, J. H.: Contribution of first- versus second-generation products to secondary organic aerosols formed in the oxidation of biogenic hydrocarbons, Environ. Sci. Technol., 40, 2283-2297, 2006.

Novakov, T. and Penner, J. E.: Large contribution of organic aerosols to cloud-condensation-nuclei concentrations, Nature, 365, 823-826, 1993.

O’Dowd, C. D., McFiggans, G., Creasey, D. J., Pirjola, L., Hoell, C., Smith, M. H., Allan, B. J., Plane, J. M. C., Heard, D. E., Lee, J. D., Pilling, M. J., and Kulmala, M.: On the photochemical production of new particles in the coastal boundary layer, Geophys. Res. Lett., 26, 1707-1710, 1999.

O'Dowd, C. D.: New particle formation and fate in the coastal environment (PARFORCE): Objectives and initial achievements, Finnish Association for Aerosol Research, Report Series in Aerosol Science, 48, 5-11, 2000.

O'Dowd, C. D.: Biogenic coastal aerosol production and its influence on aerosol radiative properties, J. Geophys. Res., 106, 1545-1550, 2001.

O’Dowd, C. D., Jimenez, J., Bahreini, R., Flagan, R., Seinfeld, J., Hämeri, K., Pirjola, L., Kulmala, M., Jennings, S. G., and Hoffmann, T.: Marine aerosol formation from biogenic iodine emissions Nature, 417, 632-636, 2002a.

O’Dowd, C. D., Hämeri, K., Mäkelä, J., Väkevä, M., Aalto, P., de Leeuw, G., Kunz, G. J., Becker, E., Hansson, H.-C., Allen, A. G.,
Harrison, R. M., Berresheim, H., Kleereld, C., Geever, M., Jennings, S. G., and Kulmala, M.: Coastal new particle formation: Environmental conditions and aerosols physicochemical characteristics during nucleation bursts, J. Geophys. Res., 107(D19), 8107, doi:10.1029/2001JD000555, 2002b.

O’Dowd, C. D., Hämeri, K., Mäkelä, J., Pirjola, L., Kulmala, M., Jennings S. G., Berresheim, H., Hansson, H.-C., de Leeuw, G., Allen, A. G., Hewitt, C. N., Jackson, A., Viisanen, Y., and Hoffmann, T.: A dedicated study of new particle formation and fate in the coastal environment (PARFORCE): Overview and objectives and initial achievements, J. Geophys. Res., 107(D19), doi: 10.1029/2001000555, 2002c.

O’Dowd, C. D., Aalto, P. P., Yoon, Y. J., and Hämeri, K.: The use of the pulse height analyzer ultrafine condensation particle counter (PHA-UCPC) technique applied to sizing of nucleation mode particles of differing chemical composition, J. Aerosol Sci., 35, 205-216, 2004a.

O’Dowd, C. D., Facchini, M. C., Cavalli, F., Ceburnis, D., Mircea, M., Dececari, S., Fuzzi, S., Yoon, Y. J., and Putaud, J.-P.: Biogenically driven organic contribution to marine aerosol, Nature, 431, 676-680, 2004b.

O’Dowd, C. D., Yoon, Y. J., Junkermann, W., Aalto, P., Kulmala, M., Lihavainen, H., and Viisanen, Y.: Airborne measurements of nucleation mode particles I: coastal nucleation and growth rates, Atmos. Chem. Phys. Discuss., 6, 8097-8123, 2006, http://www.atmos-chem-phys-discuss.net/6/8097/2006/.

Palmer, C. J., Anders, T. L., Carpenter, L. J., Küpper, F. C., and McFiggans, G. B.: Iodine and halocarbon response of Laminaria digitata to oxidative stress and links to atmospheric new particle production, Environ. Chem., 2, 282-290, 2005.

Quant, F. R., Caldow, R., Sem, G. J., and Addison, T. J.: Performance of condensation particle counters with three continuous flow design, J. Aerosol. Sci., 23, 405-408, 1992.

Röhrl, A. and Lammel, G.: Determination of malic and other $\mathrm{C}_{4}$ dicarboxylic acids in atmospheric aerosol samples, Chemosphere, 46, 1195-1199, 2002.

Rolph, G. D.: Real-time Environmental Applications and Display sYstem (READY) Website: http://www.arl.noaa.gov/ready/ hysplit4.html, NOAA Air Resources Laboratory, Silver Spring, MD, 2003.

Saiz-Lopez, A. and Plane, J. M. C.: Novel iodine chemistry in the boundary layer, Geophys. Res. Lett., 31, L04112, doi:10.1029/2003GL019215, 2004.

Sartin, J. H., Halsall, C. J., Davison, B., Owen, S., and Hewitt, C. N.: Determination of biogenic volatile organic compounds $\left(\mathrm{C}_{8}-\mathrm{C}_{16}\right)$ in the coastal atmosphere at Mace Head, Ireland, Anal. Chim. Acta, 428, 61-78, 2001.

Sartin, J. H., Halsall, C. J., Hayward, S., and Hewitt, C. N.: Emission rates of $\mathrm{C}_{8}-\mathrm{C}_{15}$ VOCs from seaweed and sand in the intertidal zone at Mace Head, Ireland, Atmos. Environ., 36, 53115321, 2002.

Saunders, R. W. and Plane, J. M. C.: Formation pathways and composition of iodine oxide ultra-fine particles, Environ. Chem., 2, 299-303, 2005.

Seinfeld, J. and Pandis, S.: Atmospheric chemistry and physics: from air pollution to climate change, John Wiley \& Sons, Inc., New York, 1998.

Sellegri, K., Yoon, Y. J., Jennings, S. G., O’Dowd, C. D., Pirjola, L., Cautenet, S., Hongwei, C., and Hoffmann, T.: Quantifica- 
tion of coastal new ultra-fine particles formation from in situ and chamber measurements during the BIOFLUX campaign, Environ. Chem., 2, 260-270, 2005.

Shaw, S. L., Chisholm, S. W., and Prinn, R. G.: Isoprene production by Prochlorococcus, a marine cyanobacterium, and other phytoplankton, Mar. Chem., 80, 227-245, 2003.

Slingo, A.: Sensitivity of the Earth's radiation budget to changes in low clouds, Nature, 343, 49-51, 1990.

Sommariva, R., Bloss, W. J., Brough, N., Carslaw, N., Flynn, M., Haggerstone, A.-L., Heard, D. E., Hopkins, J. R., Lee, J. D., Lewis, A. C., McFiggans, G., Monks, P. S., Penkett, S. A., Pilling, M. J., Plane, J. M. C., Read, K. A., Saiz-Lopez, A., Richard, A. R., Williams, P. I.: $\mathrm{OH}$ and $\mathrm{HO}_{2}$ chemistry during NAMBLEX: roles of oxygenates, halogen oxides and heterogeneous uptake, Atmos. Chem. Phys., 6, 1135-1153, 2006, http://www.atmos-chem-phys.net/6/1135/2006/.

Streitwieser, A., Heathcock, C. H., and Kosower, E. M.: Introduction to organic chemistry (4th ed.). New York: Macmillan Publishing Company, 1992.

Surratt, J. D., Murphy, S. M., Kroll, J. H., Nga, L. Ng., Hildebrandt, L., Sorooshian, A., Szmigielski, R., Vermeylen, R., Maenhaut, W., Clayes, M., Flagan, R. C., and Seinfeld, J. H.: Chemical composition of secondary organic aerosol formed from the photooxidation of isoprene, J. Phys. Chem. A, 110, 9665-9690, 2006.
Vaattovaara, P., Räsänen, M., Kühn, T., Joutsensaari, J., and Laaksonen, A.: A method for detecting presence of organic fraction in nucleation mode sized particles, Atmos. Chem. Phys., 5, 3277 3287, 2005, http://www.atmos-chem-phys.net/5/3277/2005/.

Väkevä, M., Hämeri, K., and Aalto, P. P.: Hygroscopic properties of nucleation mode and Aitken mode particles during nucleation bursts and in background air on the west coast of Ireland, J. Geophys. Res., 107(D12), 8104, doi:10.1029/2001JD001234, 2002.

Van Alstyne, K. L. and Houser, L. T.: Dimethylsulfide release during macroinvertebrate grazing and its role as an activated chemical defence, Mar. Ecol. Prog. Ser., 250, 175-181, 2003.

Weber, R. J., Marti, J., McMurry, P. H., Eisele, F. L., Tanner, D. J., and Jefferson, A.: Measurements of new particle formation and ultrafine particle growth rates at a clean continental site, J. Geophys. Res., 102, 4375-4385, 1997.

Winklmayr, W., Reischl, G. P., Lindner, A. O., and Berner, A.: A new electromobility spectrometer for the measurement of aerosol size distributions in the size range from 1 to $1000 \mathrm{~nm}$, J. Aerosol Sci., 22, 289-296, 1991.

Zubay, G.: Biochemistry (4th ed.), Dubuque, IA : WCB, cop., 1998. 